\title{
Facies architecture and Late Pliocene - Pleistocene evolution of a felsic volcanic island, Milos, Greece
}

Received: 18 August 2004 / Accepted: 11 November 2005 / Published online: 9 February 2006

(C) Springer-Verlag 2005

\begin{abstract}
The volcanic island of Milos, Greece, comprises an Upper Pliocene-Pleistocene, thick (up to $700 \mathrm{~m}$ ), compositionally and texturally diverse succession of calcalkaline, volcanic, and sedimentary rocks that record a transition from a relatively shallow but dominantly belowwave-base submarine setting to a subaerial one. The volcanic activity began at $2.66 \pm 0.07 \mathrm{Ma}$ and has been more or less continuous since then. Subaerial emergence probably occurred at $1.44 \pm 0.08 \mathrm{Ma}$, in response to a combination of volcanic constructional processes and faultcontrolled volcano-tectonic uplift. The architecture of the dominantly felsic-intermediate volcanic succession reflects contrasts in eruption style, proximity to source, depositional environment and emplacement processes. The juxtaposition of submarine and subaerial facies indicates that for part of the volcanic history, below-wave base to abovewave base, and shoaling to subaerial depositional environments coexisted in most areas. The volcanic facies architecture comprises interfingering proximal (near vent), medial and distal facies associations related to five main volcano types: (1) submarine felsic cryptodome-pumice cone volcanoes; (2) submarine dacitic and andesitic lava domes; (3) submarine-to-subaerial scoria cones; (4) submarine-tosubaerial dacitic and andesitic lava domes and (5) subaerial lava-pumice cone volcanoes. The volcanic facies are
\end{abstract}

Electronic Supplementary Material Supplementary material is available for this article at

http://dx.doi.org/10.1007/s00445-005-0045-2

Editorial responsibility: J. Gilbert

A. L. Stewart $(\bowtie) \cdot J$. McPhie

Centre for Ore Deposit Research and School of Earth Sciences,

University of Tasmania,

Private Bag 79, Hobart, Tasmania 7001, Australia

e-mail: astewart@ivanhoemines.com

Tel.: +61291811044

Present address:

A. L. Stewart

Ivanhoe Mines Mongolia Inc. - Exploration, Gobi House, Khan

Uul District,

Orgil Khotkhon, Ulaanbaatar, Mongolia interbedded with a sedimentary facies association comprising sandstone and/or fossiliferous mudstone mainly derived from erosion of pre-existing volcanic deposits. The main facies associations are interpreted to have conformable, disconformable, and interfingering contacts, and there are no mappable angular unconformities or disconformities within the volcanic succession.

Keywords Volcanic facies architecture - Shallow marine volcanism $\cdot$ Felsic dome-cryptodome-pumice cone volcanoes - Southern Aegean Volcanic Arc - SHRIMP . Geochronology

\section{Introduction}

Less research has been carried out on felsic volcanic islands or seamounts than on their mafic counterparts, despite their abundance in modern oceans and in ancient volcanic successions. The growth and development of submarine felsic volcanoes are difficult to observe, and there are few records of eruptions (e.g. 1953-1957 Tuluman eruption, Reynolds et al. 1980; 1952-1953 Myojinsho eruption, Fiske et al. 1998). Volcanological studies rely on data from modern oceanographic submersible surveys (e.g. Yuasa 1995; Fiske et al. 2001), bathymetric surveys (e.g. Yamamoto et al. 1991; Yuasa et al. 1991; Fiske et al. 2001) and dredge sampling (e.g. Kato 1987; Wright and Gamble 1999; Wright et al. 2003), and from ancient successions that have been uplifted to subaerial settings (e.g. Fiske and Matsuda 1964; Pichler 1965; de Rosen-Spence et al. 1980; Allen 1992; McPhie and Allen 1992; Kerr and Gibson 1993; Sohn 1995; Allen et al. 1996; Brown et al. 2002). Felsic volcanic successions that preserve complete submarine-to-subaerial transitions, and in which depositional settings are well constrained, are uncommon. Hence, knowledge of the volcanic facies associations and the eruption styles that generate them, and of the evolution of felsic volcanic islands, is limited. Understanding these complex felsic submarine-tosubaerial successions is important because they may host 
substantial precious and base metal ore deposits (e.g. Eskay Creek, Roth et al. 1999; Boliden, Allen et al. 1996; Horne, Kerr and Gibson 1993; Lerokis and Kali Kuning, Sewell and Wheatley 1994).

Here we examine the submarine-to-subaerial, dominantly felsic volcanic succession of Milos, Greece. This paper describes and interprets the volcanic geology of Milos, presenting new information on the character and geometry of volcanic facies associations, types of volcanoes and locations and depositional settings of volcanic centres. We review existing geochronological data, and, together with new $\mathrm{U}-\mathrm{Pb}$ in zircon dates, present a time-stratigraphic framework for the evolution of Milos.

\section{Regional geology of Milos}

The small archipelago of Milos is situated in the central part of the modern Southern Aegean Volcanic Arc (SAVA; Fig. 1). These volcanic islands lie in an area of complex extensional and subduction-related tectonics (Jackson 1994). The SAVA is the surface expression of active, northward subduction of the African plate beneath the Aegean microplate. The arc is no more than $20 \mathrm{~km}$ wide, and stretches from Crommyonia in the west, through Methana, Aegina, Milos, Santorini, to Nisyros and Kos in the east (Fig. 1; Innocenti et al. 1979; Fytikas et al. 1984). Arc volcanism began at the end of the Early Pliocene (McKenzie 1978 PePiper et al. 1983; Fytikas et al. 1984; Mercier et al. 1989). Methana, Milos, Santorini and Nisyros have each had his-

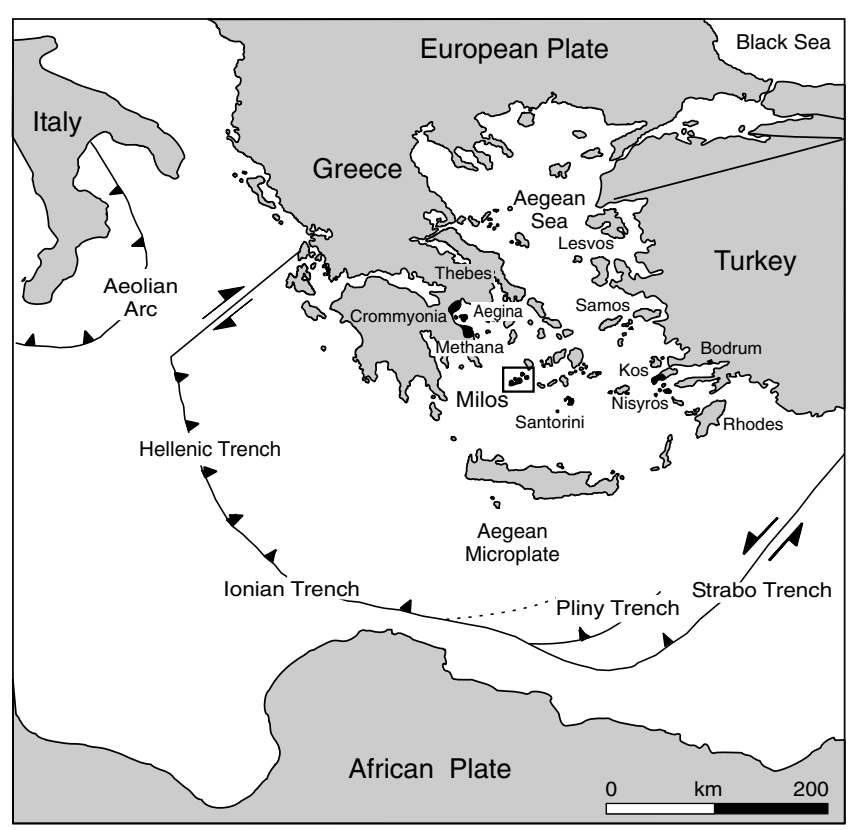

Fig. 1 Simplified regional geotectonic map of the eastern Mediterranean, based on Jackson (1994). The volcanic centres of Southern Aegean Volcanic Arc (SAVA; in black) extend from Crommyonia in the west to the islands of Kos and Nisyros in the east. The Hellenic, Ionian, Pliny and Strabo trenches mark the subduction zone between the African Plate and the Aegean Microplate toric eruptions and are best considered dormant (Keller et al. 1990).

The arc volcanoes lie above a Benioff Zone at 130$150 \mathrm{~km}$ depth, and are about $200 \mathrm{~km}$ from the Hellenic Trench (Dewey and Sengör 1979; Keller 1982). Fault-plane solutions for earthquakes along the arc are normal in character (McKenzie 1978; Jackson 1994). Therefore, despite the compressive stress regime associated with subduction, the arc has developed in an extensional environment.

Milos island is the largest of four islands in the Milos archipelago. The neighbouring islands of Kimolos and Polyegos composed of submarine and subaerial, calcalkaline volcanic and submarine sedimentary rocks that are broadly similar to those on Milos (Fytikas et al. 1986). The volcanic rocks are predominantly rhyolite and dacite, with subordinate andesite and basaltic andesite (Fytikas et al. 1986). The island of Antimilos is dominated by dacitic and andesitic lavas, and minor pyroclastic units, and is thought to represent the uppermost part of a polygenetic composite volcano (Fytikas et al. 1986).

\section{Stratigraphic framework of Milos}

The Milos volcanic succession occupies approximately $151 \mathrm{~km}^{2}$ and has a maximum thickness of $700 \mathrm{~m}$ (Fig. 2; Fytikas and Marinelli 1976). The succession is composed of calc-alkaline volcanic and sedimentary rocks (Fytikas et al. 1986). The volcanic rocks predominantly have rhyolitic and dacitic compositions; andesitic compositions are subordinate (Fig. 3; Fytikas et al. 1986). The stratigraphy exposed on Milos shows an upward progression from submarine to subaerial depositional environments (Fytikas et al. 1986).

The volcanic succession on Milos was first described by Sonder (1924). The most recent of several attempts (Fytikas and Marinelli 1976; Angelier et al. 1977) at establishing the volcanic stratigraphy on Milos was the systematic study by Fytikas et al. (1986), based on mapping of the island at 1:25 000 scale (Fytikas et al. 1977). The informal regional stratigraphy defined by Fytikas et al. (1986) consists of: the Mesozoic metamorphic group, the Neogene sedimentary group, the basal pyroclastic series (Middle-Late Pliocene), the complex of domes and lava flows series (Late Pliocene), the pyroclastic series and lava domes (Early Pleistocene), the rhyolitic complex of Firiplaka and Trachilas series (Late Pleistocene) and the products of phreatic activity (Late Pleistocene to present).

The Mesozoic metamorphic group (Cycladic Crystalline Complex) forms the basement to the volcanic units and consists principally of chlorite, actinolite and glaucophane schists and metapelites of greenschist and blueschist facies (Fytikas and Marinelli 1976; Hoffmann and Keller 1979; Kornprobst et al. 1979; Fytikas et al. 1986). The Neogene sedimentary group ( $\sim 180$ m thick) comprises brown to red limestone intercalated with basement-derived conglomerate, breccia and sandstone.

The basal pyroclastic series (equivalent to the 'Old Tuffs' of Fytikas 1977) has a minimum stratigraphic 


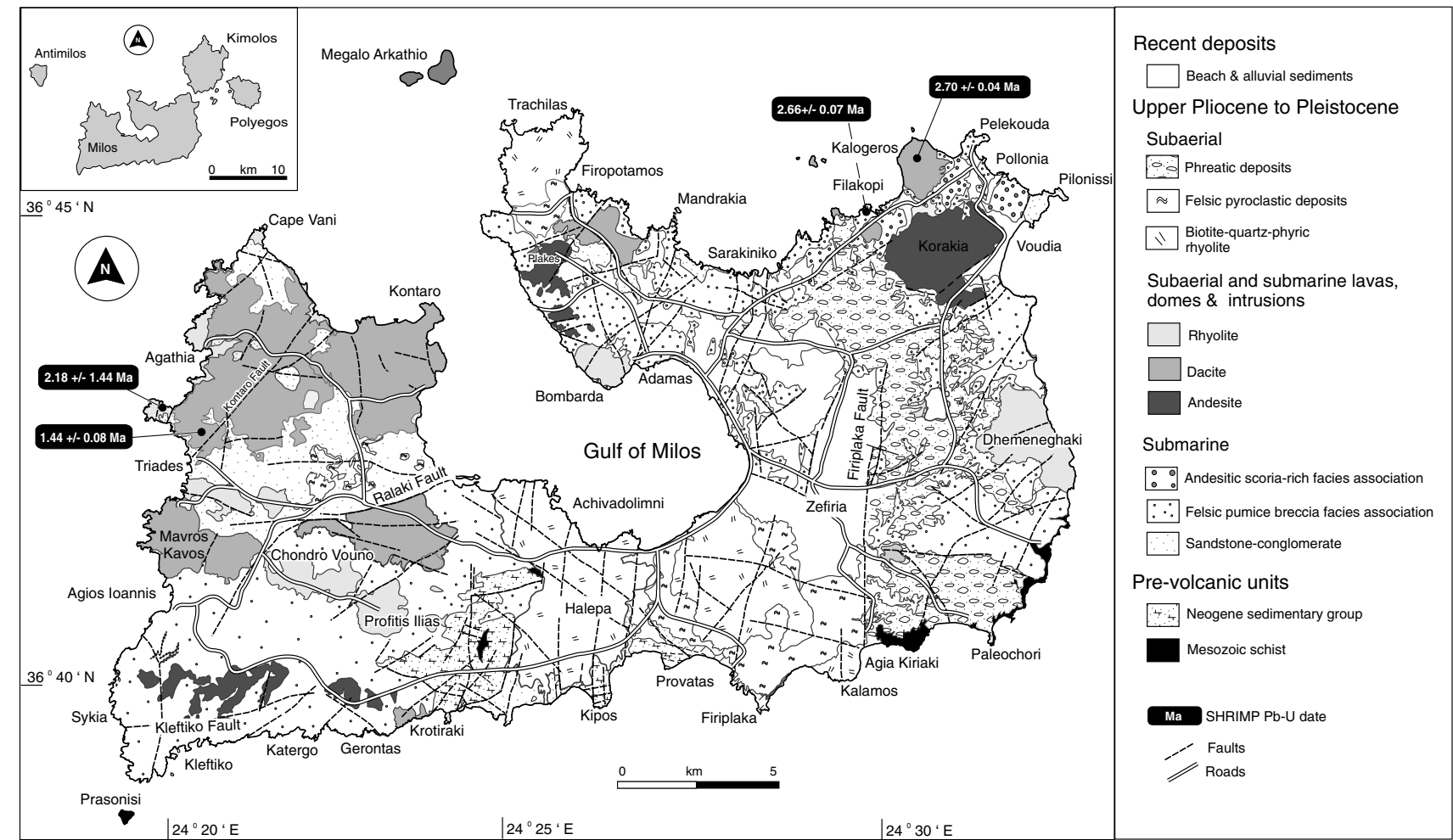

Fig. 2 Simplified geological map of Milos showing the distribution of the main volcanic facies association and structure, modified after Fytikas (1986).

thickness of $120 \mathrm{~m}$, and dominates the southwestern sector of Milos (Fig. 2). Fytikas et al. (1986) reported that the succession is dominated by "submarine pyroclastic flows, tuff pumice flows, pillow lavas and pillow breccia". The complex of domes and lava flows series is mainly composed of massive and flow-banded dacite and andesite and breccia, mostly forming domes and lavas which are typically 100-150 m thick (Fytikas and Marinelli 1976).

The third unit (pyroclastic series and lava domes) is dominated by rhyolitic lavas, domes and pumiceous volcaniclastic units (Fytikas et al. 1986) that are restricted to the eastern and northern parts of the island (Fig. 2). Fytikas et al. (1986) divided this unit into three, loosely defined parts: the lower pyroclastic series, lava domes and the upper Halepa and Plakes domes. Firiplaka and Trachilas are two subaerial rhyolitic volcanic centres at Firiplaka (Campos Venuti and Rossi 1996) in the south and Trachilas in the north (Fig. 2). Each volcanic centre consists of distinctive quartz-biotitephyric rhyolitic lava and pumiceous pyroclastic deposits (Fytikas et al. 1986; Campos Venuti and Rossi 1996). The youngest volcanic unit (products of phreatic activity) mainly occurs in the southeastern sector of the island (Fig. 2; Fytikas et al. 1986). The deposits included in this unit have lateral extents up to a few hundred metres and have maximum thicknesses of $30 \mathrm{~m}$. Quaternary sedimentary units (sand, silt and minor gravel) also occur on Milos but are typically restricted to the Zefiria plain (Fig. 2), and relatively thin (tens of metres)(Fytikas and Marinelli 1976).

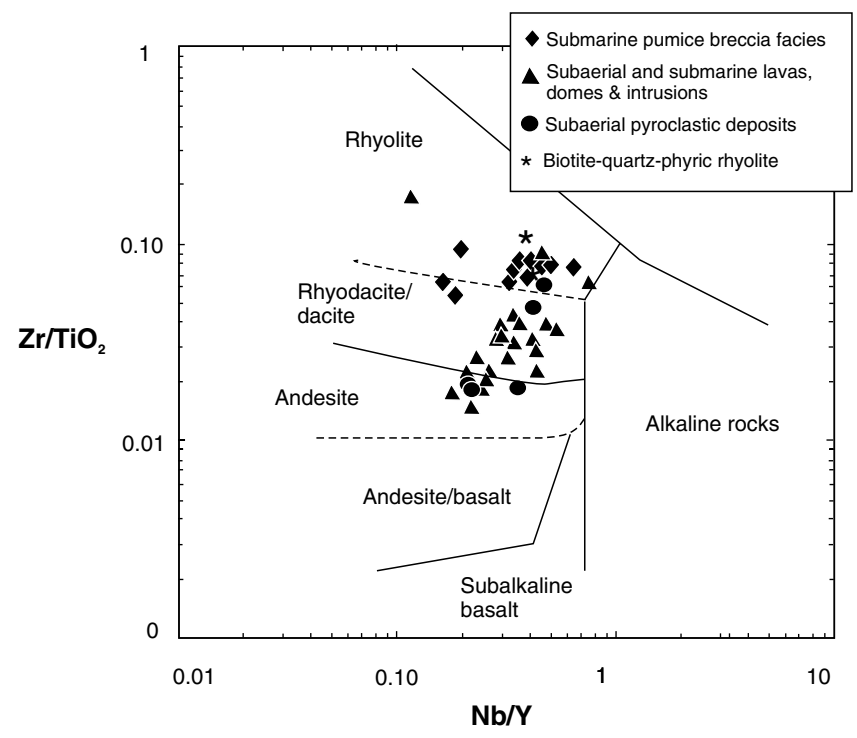

Fig. $3 \mathrm{Zr} / \mathrm{TiO} 2$ versus $\mathrm{Nb} / \mathrm{Y}$ diagram (after Winchester and Floyd 1977). The Milos volcanic rocks are andesites, dacites and rhyolites. All the rocks are subalkaline, based on the $\mathrm{Nb} / \mathrm{Y}$ ratio

\section{Structure of Milos}

The volcanic succession of Milos is only gently deformed. Bedding in volcaniclastic and sedimentary formations on Milos is generally flat-lying or gently dipping. The succession is disrupted by normal faults, some of which have displacements up to several hundred metres (Fytikas 

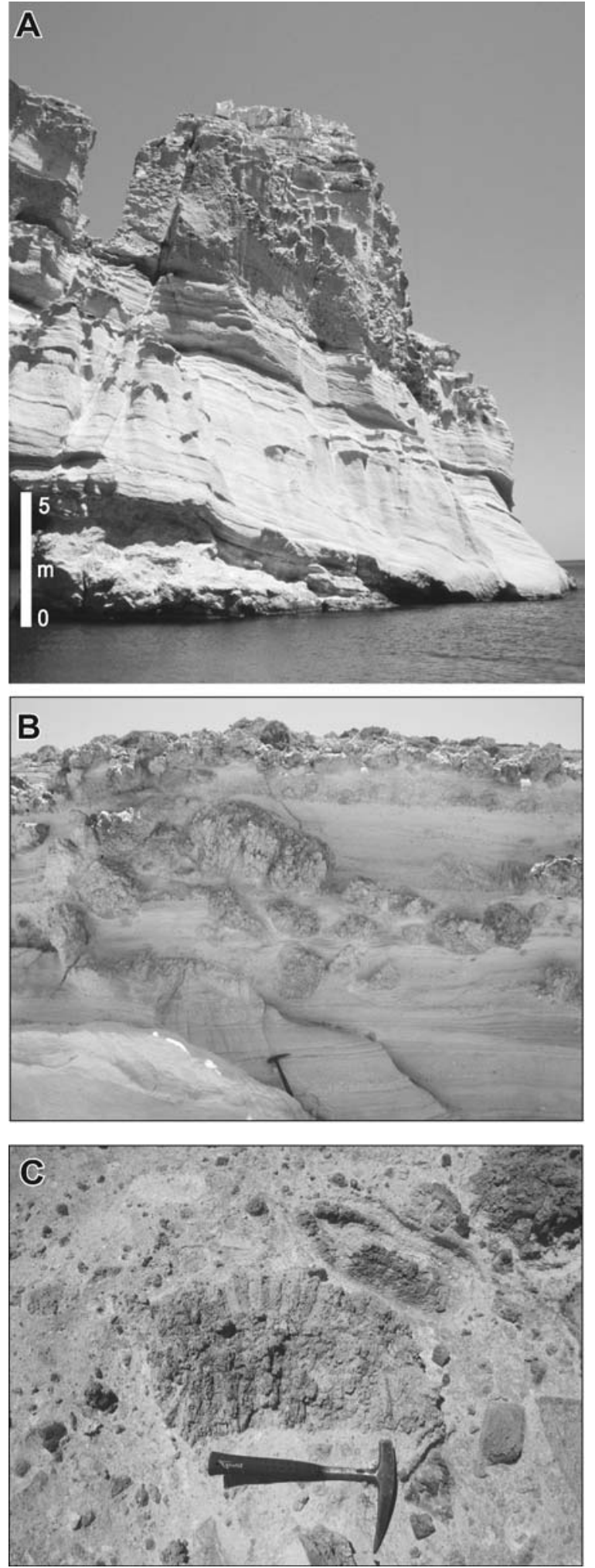

Fig. 4 A Thick succession of submarine felsic pumice breccia exposed in the Kleftiko Headland (pumice breccia facies association). B Very coarse pumice clasts set in a matrix of fine $(1-2 \mathrm{~cm})$ pumice clasts (stratified pumice breccia facies) at Filakopi. C Prismatic rhyolitic pumice clast with normal joints along the margins and internal polyhedral joints (coarse pumice breccia facies) at Filakopi. These joint patterns probably result from quenching of hot pumice in water
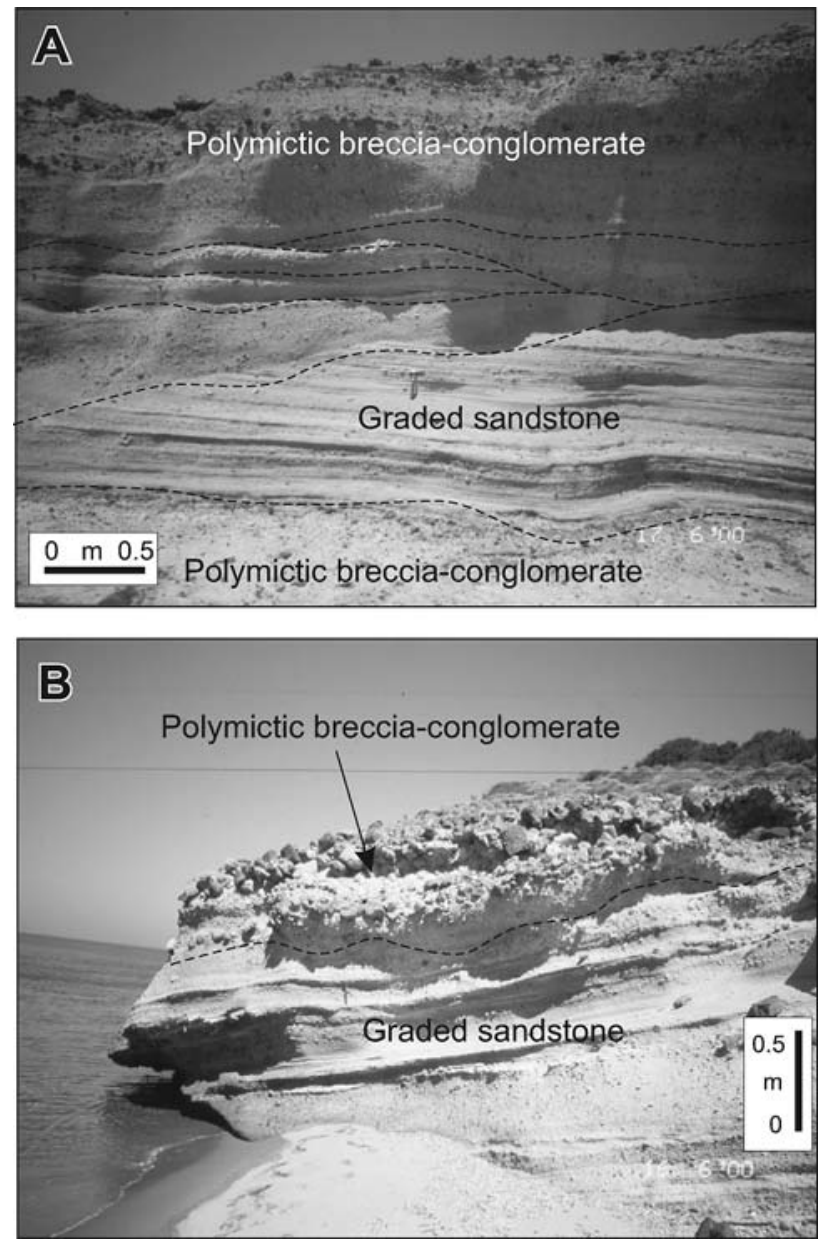

Fig. 5 Submarine sandstone and conglomerate. A Graded sandstone interbedded with thin $(<0.5 \mathrm{~m})$ intervals of polymictic brecciaconglomerate at Sarakiniko. Note the high-angle truncation of bedding (above the hammer). B Submarine graded sandstone interbedded with redeposited hyaloclastite at Triades

et al. 1986), and by numerous syn-volcanic intrusions. The subvertical normal faults interacted during periods of extension to produce horsts and grabens (Fytikas and Marinelli 1976). Three main episodes of deformation have been recognised in the Late Pliocene - Pleistocene (Angelier et al. 1977; Fytikas 1989).

The earliest episode of extension produced eastnortheast-striking normal faults that controlled uplift of Mesozoic and Neogene basement in the southwest. The faults may have controlled emplacement of dacite domes and lavas (Fig. 2). A second episode resulted in several northeast-striking normal faults predominantly in the central and eastern sector of the island. These faults formed the Zefiria Graben, and probably influenced the location of some volcanic centres (Fytikas 1989). The final extensional phase produced northwest-striking faults that define Milos Gulf in the centre of the island (Fig. 2). The volcanic centres of Firiplaka and Trachilas occur at either end of the Milos Gulf graben. The central part of the island is considered structurally active (Fytikas 1989). This area includes four young phreatic centers, active fumaroles and solfataras 
(Botz et al. 1996; Stüben and Glasby 2001) and was the focus of seismic activity in March 1922 (with focal depths between 1 and 4 km, Papazachos 1990; Papanikolaou et al. 1993).

In places, syn-volcanic intrusions have disturbed the succession (e.g. Stewart and McPhie 2003) and locally caused up-doming of overlying clastic units. However, this deformation is generally restricted to within a few hundred metres of the margins of the intrusions.

\section{Volcanic and sedimentary facies associations}

Facies analysis

The stratigraphy proposed by Fytikas et al. (1986) provided a very useful framework for facies analysis. However, for much of the succession, the stratigraphic approach is inadequate because it masks the diversity and complexity among the volcanic units and implies the presence of distinct mappable units. The entire Milos succession is mainly felsic and there are no clear spatial or temporal trends toward more or less mafic compositions. All parts of the succession also include the products of both effusive (or shallow intrusive) and explosive eruptions. The single major change shown by the succession relates to the depositional setting - the lower part is submarine, the upper part is subaerial and the intermediate part records the transition from submarine to subaerial environments.

In order to examine the evolution of the island, we have undertaken facies analysis. Facies and facies associations (Table 1) were defined on the basis of systematic field mapping and core logging. The volcanic facies associations have genetic significance with respect to volcano type, eruption style, proximity to source and emplacement processes. Information on the volcano types and depositional settings has been combined with a new geochronological framework to reconstruct the volcanic evolution of the island.

Volcanic and sedimentary facies associations

Nine compositionally and texturally distinct facies associations have been identified (Table 1). Five of the facies associations are the products of effusive eruptions and/or shallow intrusive processes (lavas, domes, cryptodomes, dykes): (1) the rhyolite facies association comprises coherent rhyolite and sediment-matrix rhyolite breccia; (2) the biotite-quartz-phyric rhyolite facies association comprises coherent biotite-quartz-phyric rhyolite and clastsupported monomictic biotite-quartz-phyric rhyolite breccia; (3) the dacite facies association comprises coherent dacite, non-stratified or stratified or clast-supported monomictic dacite breccia and sediment-matrix dacite breccia; (4) the andesite facies association comprises coherent andesite, non-stratified or clast-supported and stratified monomictic andesite breccia and sediment-matrix andesite breccia.
These facies associations have been named on the basis of composition (cf. McPhie et al. 1993), as indicated by phenocryst assemblages and immobile element ratios $(\mathrm{Zr} / \mathrm{TiO} 2$ versus $\mathrm{Nb} / \mathrm{Y}$, Fig. 3). The rhyolites in the succession have $10-15$ vol.\% phenocrysts and are either feldspar-quartzphyric, biotite-feldspar-quartz-phyric or biotite-quartzphyric. The quartz (8-10 vol.\%), feldspar and biotite phenocrysts are mainly in the $1-3 \mathrm{~mm}$ size range. The majority of dacites comprise 8-20 vol.\% phenocrysts of feldspar, biotite and quartz ( $<5$ vol.\%) mainly in the $0.5-2 \mathrm{~mm}$ size range. The andesites contain $10-20$ vol. $\%$ phenocrysts, including $1-2 \mathrm{~mm}$ plagioclase (10-15 vol.\%) and $1 \mathrm{~mm}$ hornblende (5-8 vol.\%).

Four of the facies associations are the products of explosive eruptions that generated a variety of pyroclastic deposit types, and have been named according to the dominant components and grain sizes (Table 1): (5) the pumice breccia facies association consists of coarse pumice breccia, stratified pumice breccia, lithic-pumice breccia and graded pumice breccia; (6) the scoria-rich breccia facies association consists of cross-stratified scoria breccia, massive andesitic breccia and fine scoria sandstone; (7) the pyroclastic facies association comprises matrix-supported coarse dacite or andesite breccia, cross-bedded lapilli-ash and bedded ash; (8) the mud-matrix lithic breccia facies association comprises massive schist-rich breccia (equivalent to the 'Green Lahar' of Fytkas et al. 1977) and polymictic mud-matrix breccia. The ninth facies association comprises graded sandstone, thickly bedded to laminated mudstone, and polymictic breccia-conglomerate collectively referred to as the sandstone-conglomerate facies association.

\section{Depositional environments}

Few single facies are independently diagnostic of eruptive or depositional environments. Three main criteria have been used for distinguishing submarine volcanic and sedimentary facies from subaerial facies on Milos: (1) presence of marine ichnofacies and/or marine fossils in sedimentary facies; (2) presence of depositional structures characteristic of subaqueous deposition, in particular, tabular, massive to graded beds typical of deposits from water-supported particulate gravity currents, angleof-repose cross-stratification and ripple cross-lamination; and (3) presence of juvenile volcanic clasts with quenched margins and volcaniclastic aggregates interpreted to be the products of quench fragmentation (hyaloclastite). In conjunction, three criteria have been used for identifying subaerial facies: (1) presence of palaeosols; (2) the presence of pyroclastic density current deposits (primarily surge deposits and block-and-ash-flow deposits) that contain evidence of hot emplacement, such as thermal oxidation and/or carbonised wood and vegetation; and (3) the presence of accretionary lapilli in undisturbed pyroclastic deposits.

Some facies associations are exclusively submarine. For example, the pumice breccia facies association comprises thickly bedded (tens of metres), diffusely stratified, rhyolitic to dacitic pumice breccia (Fig. 4A and B) 


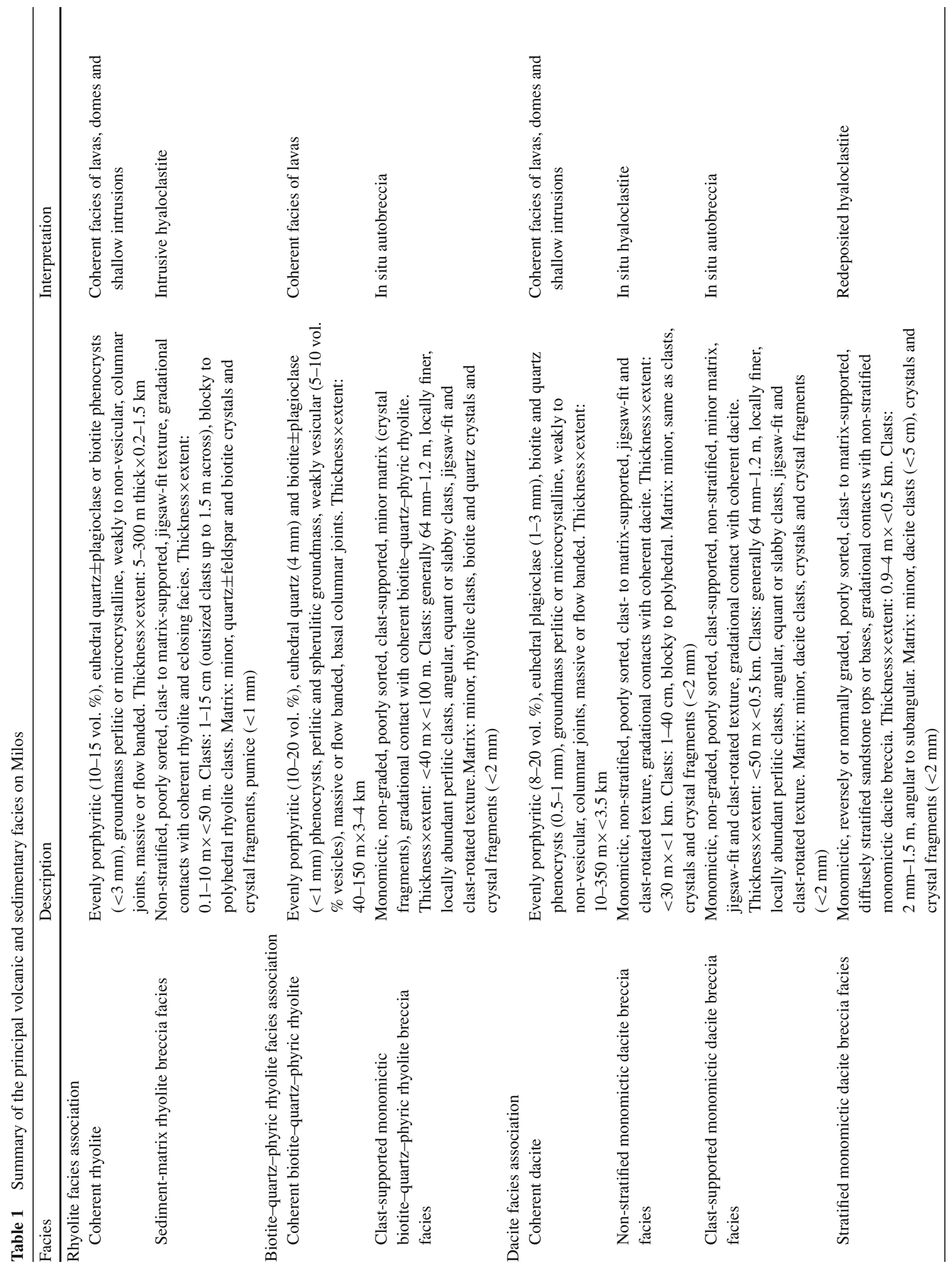




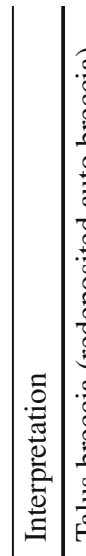
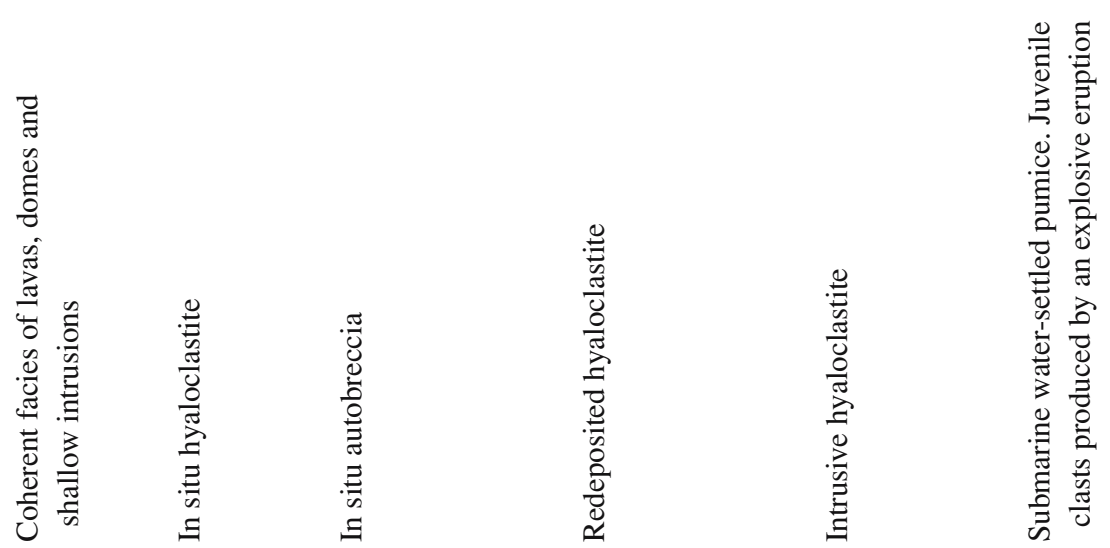

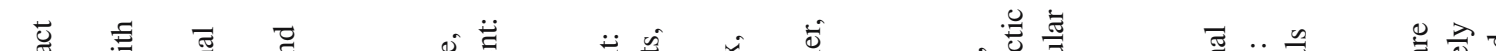

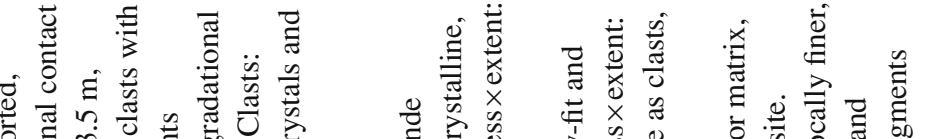

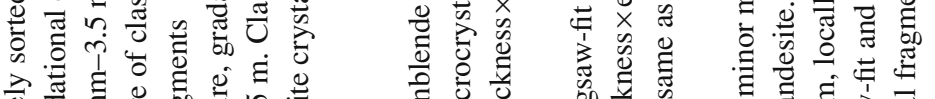

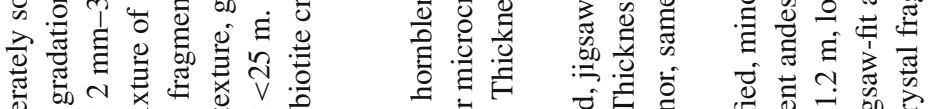

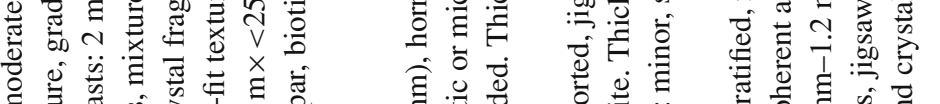

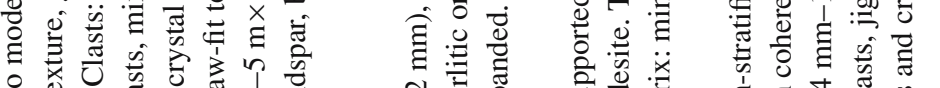

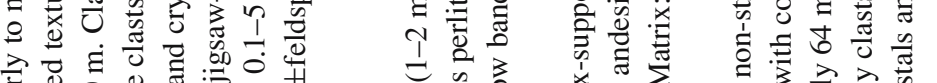

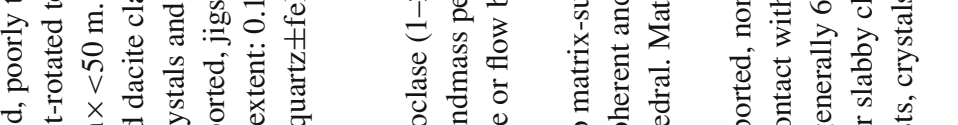

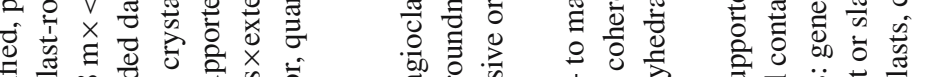

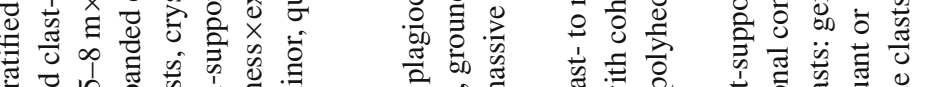

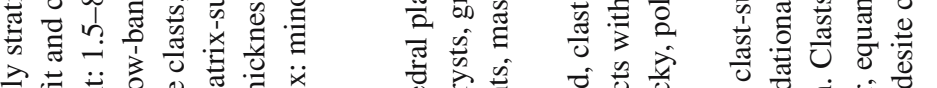

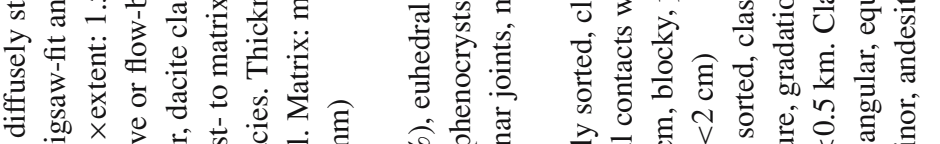

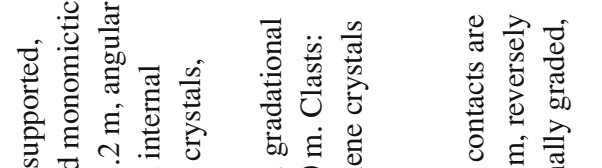

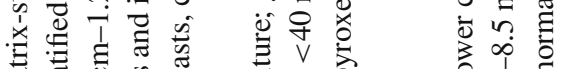

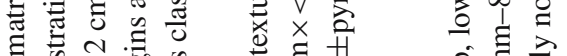

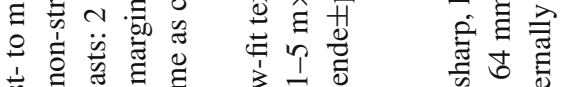

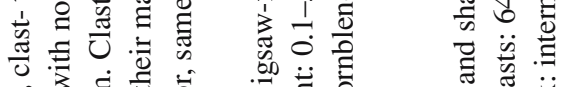

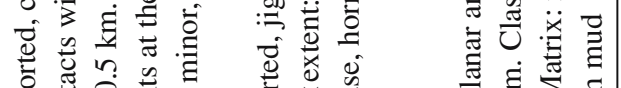

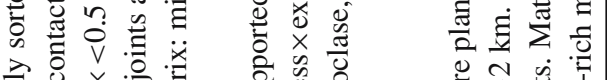

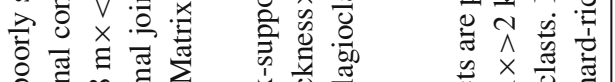

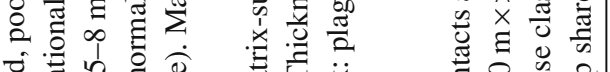

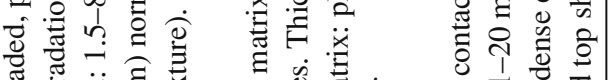

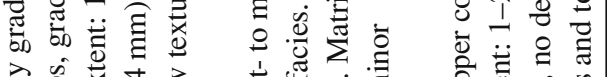

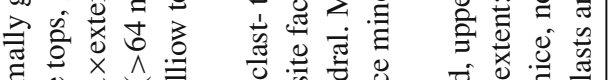

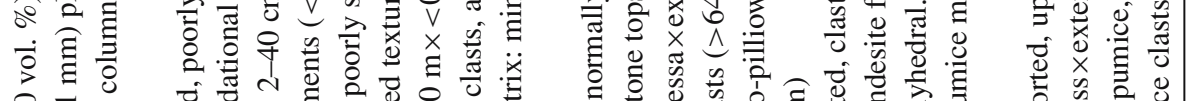

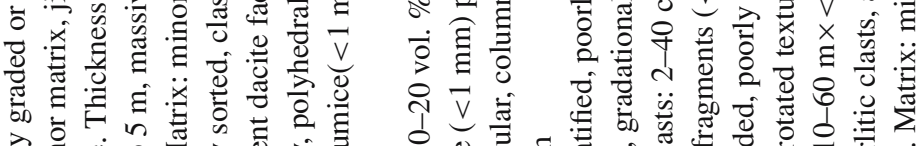

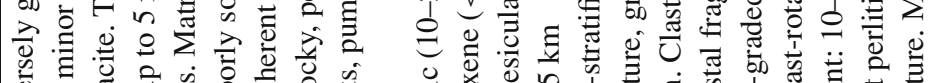

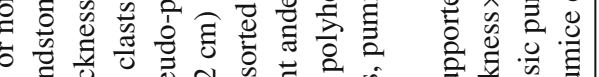

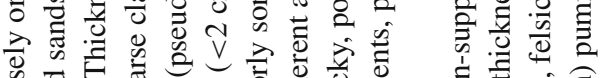

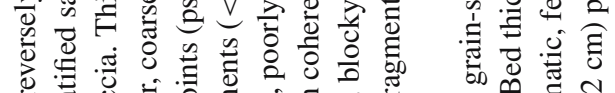

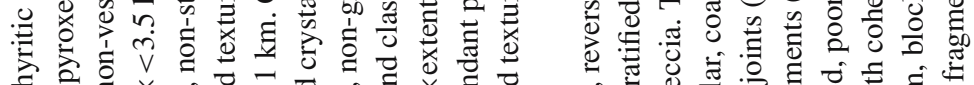

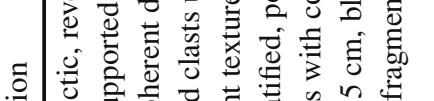

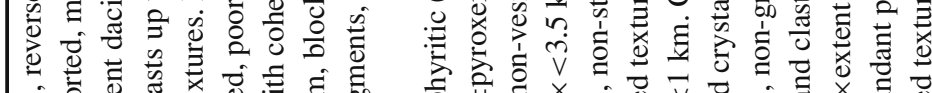

:

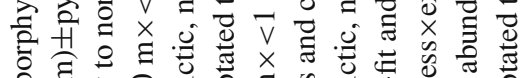

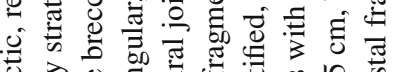

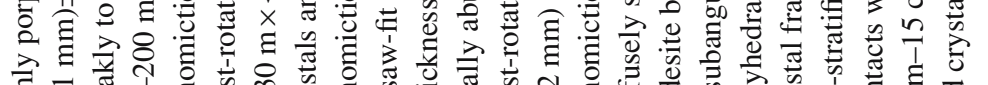

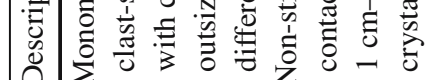

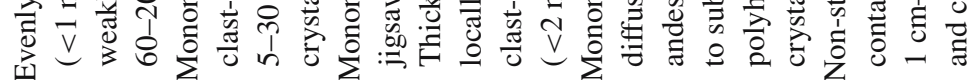
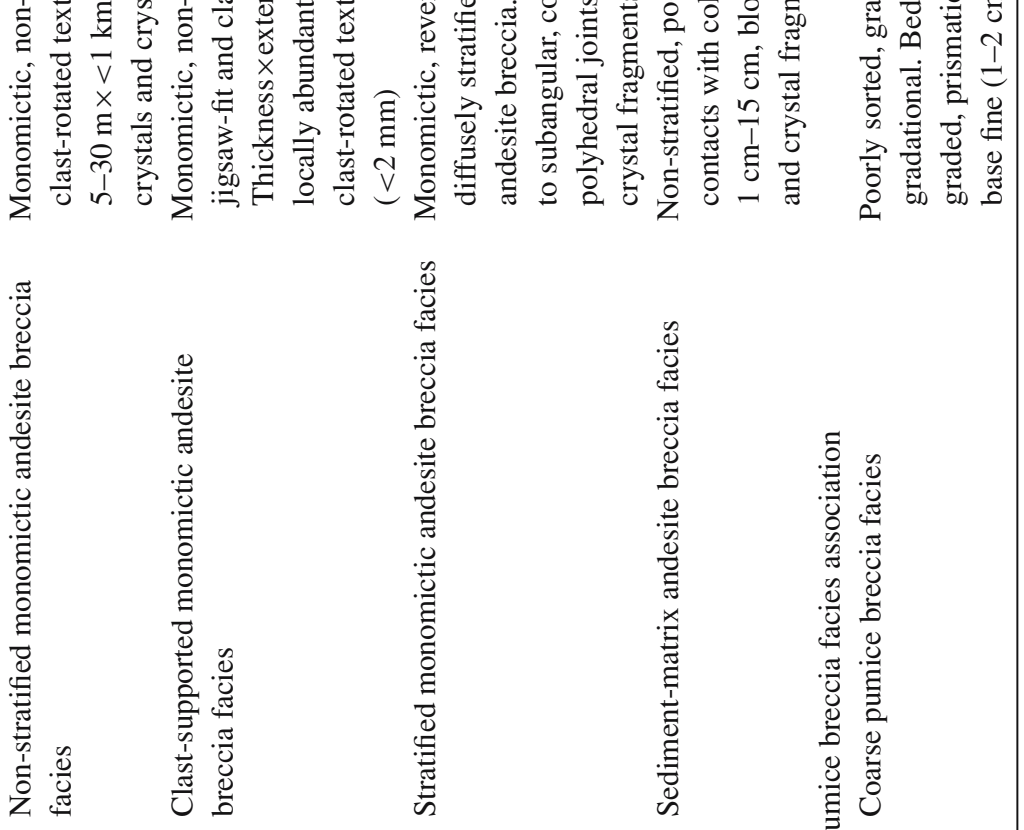

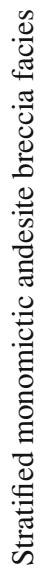

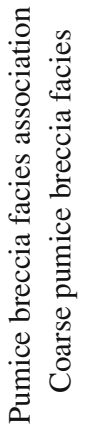




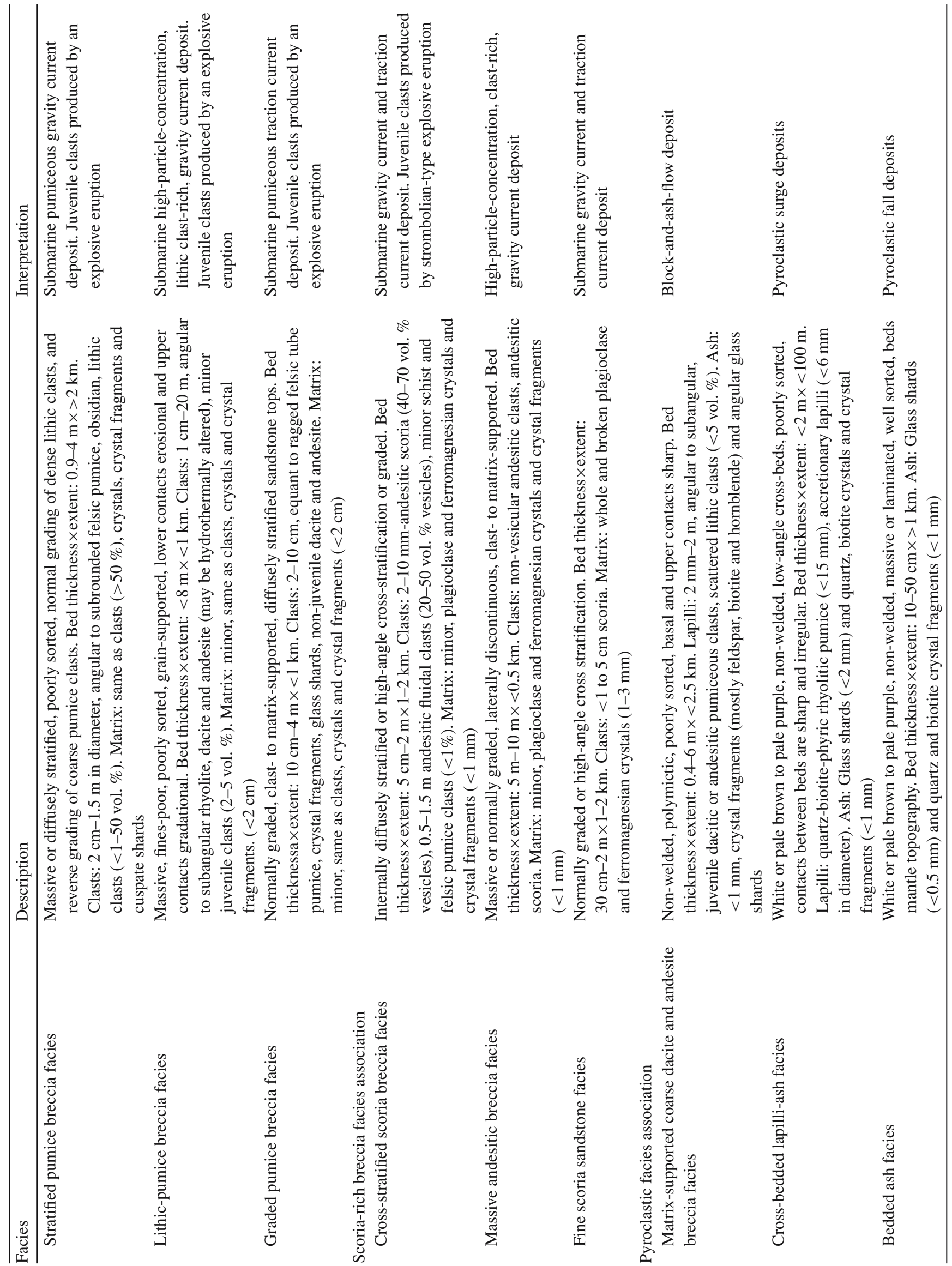




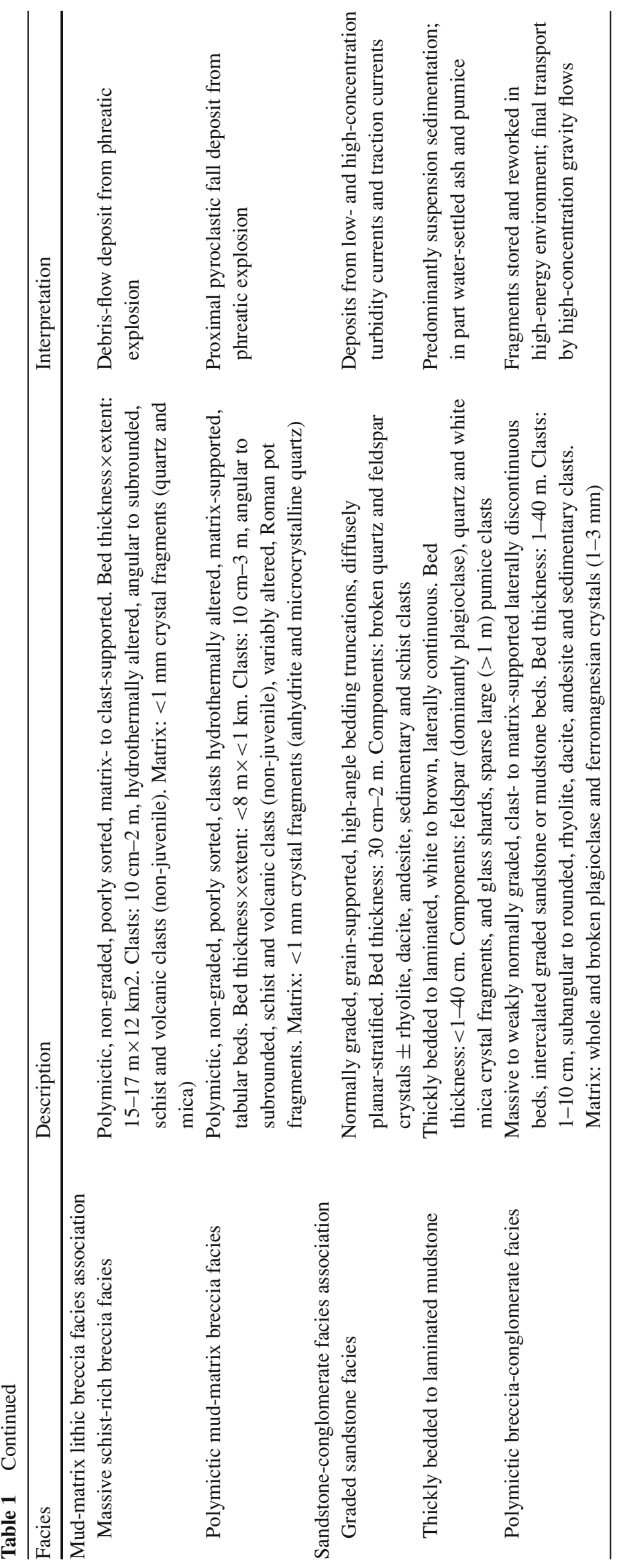


Fig. 6 A Subaerial rhyolite lava of the Trachilas rhyolitic complex on the coast at Tsigardo. A thick interval of coherent biotite-quartz-phyric rhyolite is enclosed in autobreccia that shows both clast-rotated and jigsaw-fit textures. B Subaerial autobreccia at the distal margin of the biotite-quartz-phyric rhyolite lava erupted from the Firiplaka rhyolitic complex (Fig. 2)
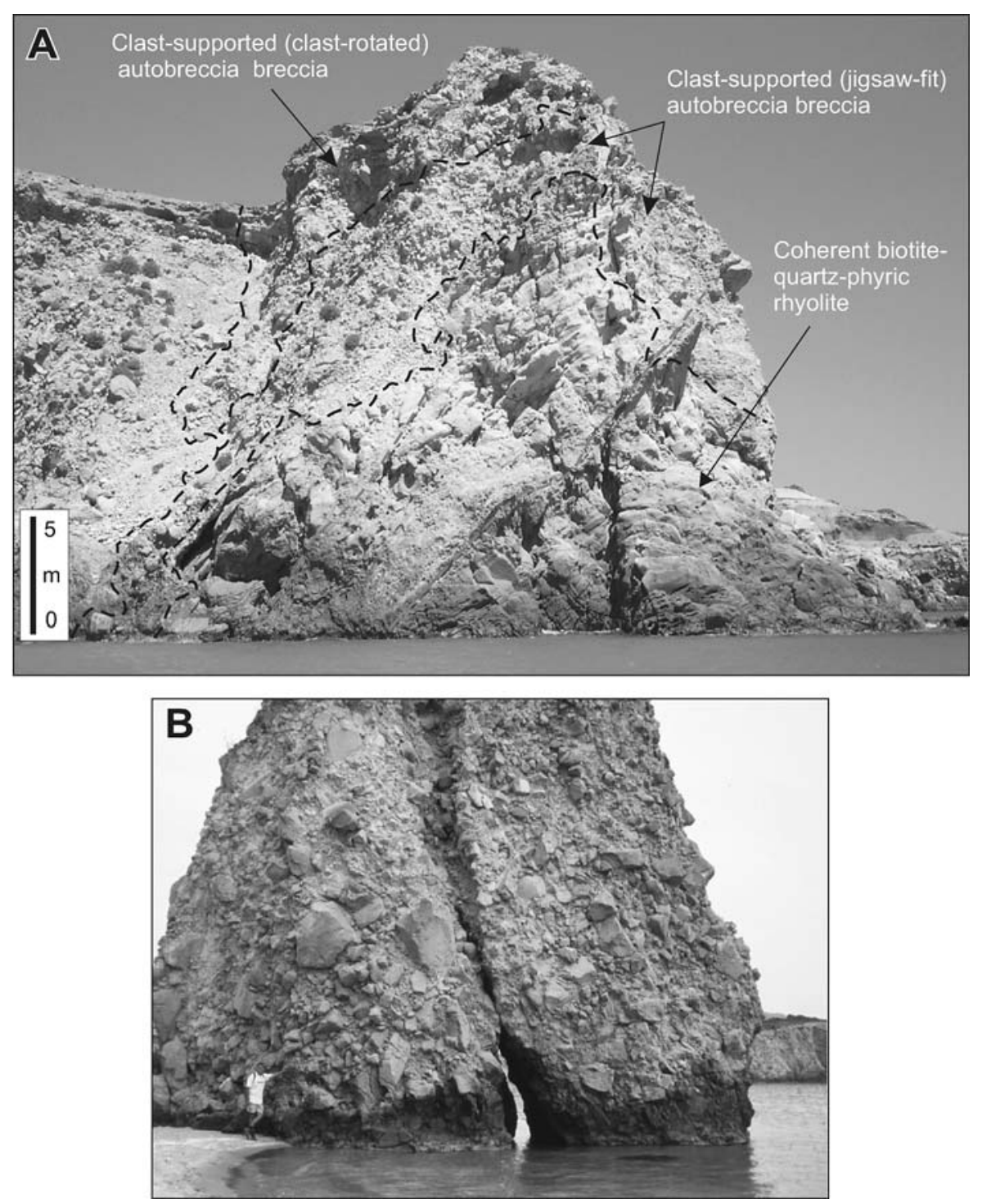

interbedded with locally abundant graded sandstone and mudstone facies. The pumice breccia facies is composed of unmodified juvenile pumice clasts produced by explosive eruptions (Fig. 4C). However, the bed forms indicate that transport and deposition involved water-supported gravity currents and settling from suspension in the water column (e.g., Stewart and McPhie 2004).

Although volumetrically minor, the sandstoneconglomerate facies association (Fig. 5) is also exclusively submarine. Bioturbation and marine fossils in the mudstone facies imply deposition in a relatively shallow-water environment, up to a few hundred metres deep. The presence of tabular, massive to graded beds typical of deposits from gravity currents and sedimentary structures indicative of wave action and currents (e.g. cross-stratification) are also consistent with a shallow submarine environment close to wave base.

Some facies associations are exclusively subaerial. The Firiplaka and Trachilas rhyolitic volcanic complexes are the most prominent examples. These two complexes consist of biotite-quartz-phyric rhyolitic lavas (biotitequartz-phyric rhyolite facies association; Fig. 6A and B) and cross-bedded lapilli-ash and bedded ash facies (pyroclastic facies association; Campos Venuti and Rossi 1996). The Halepa biotite-quartz-phyric rhyolitic lavas is also subaerial. The common occurrence of palaeosols, charcoal-bearing pyroclastic units, and autobreccia, and absence of intercalated sedimentary facies in these associations indicate that the environment was subaerial (Fig. 7A-C).

Some facies associations include submarine, subaerial and shallow intrusive emplacement units. For example, some of the domes in the dacite facies association are submarine and characterised by combinations of coherent facies, in situ hyaloclastite, intrusive hyaloclastite and redeposited hyaloclastite (Fig. 8A). Other domes are subaerial and characterised by the presence of autobreccia and talus. The shallow intrusions typically include significant intrusive hyaloclastite, and lack redeposited autoclastic facies (Fig. 8B). 

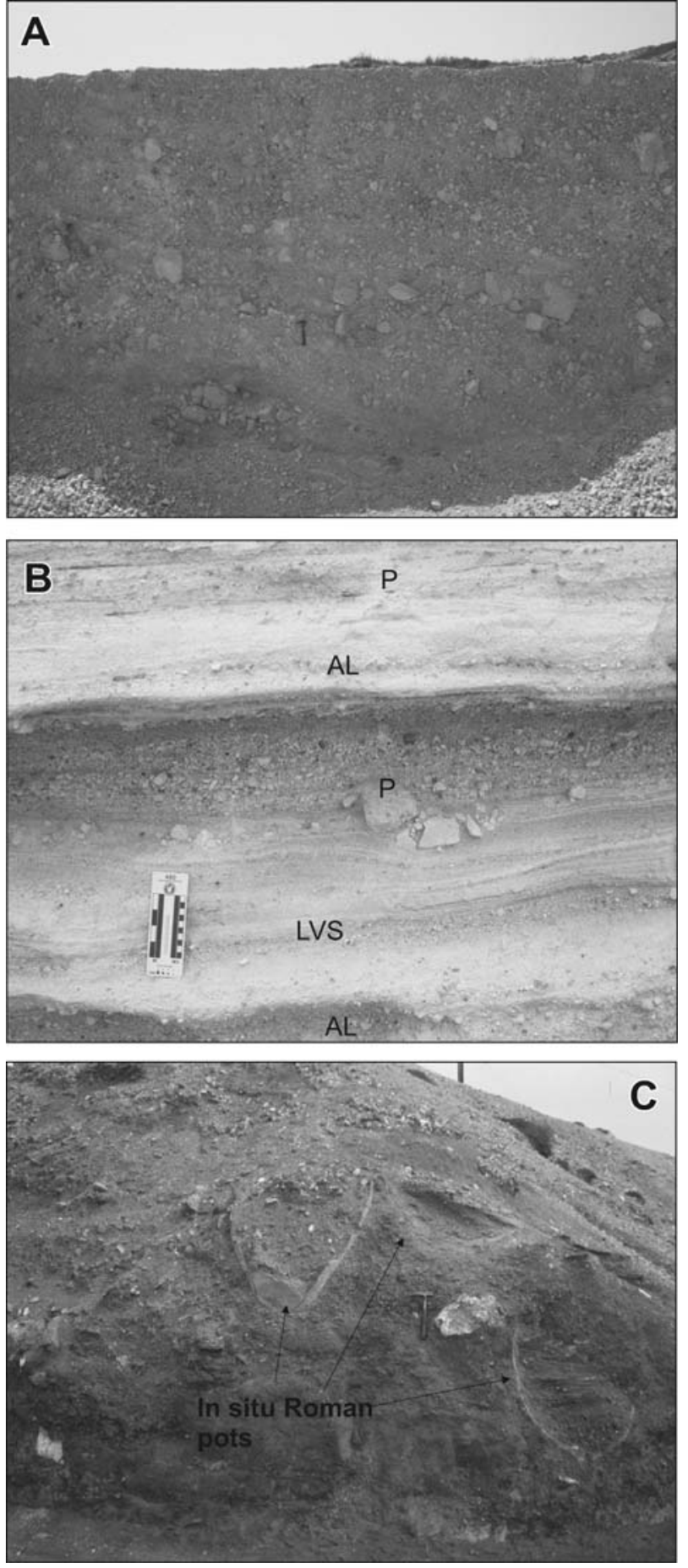

Fig. 7 A Subaerial block-and-ash flow deposit generated by explosive eruptions at the Firiplaka rhyolitic complex. Poorly sorted interval of coarse breccia at Firiplaka. The deposit is poorly sorted and composed of matrix-supported, angular to subangular, juvenile rhyolite clasts $(2 \mathrm{~mm}-1.5 \mathrm{~m}$ in diameter). B Subaerial rhyolitic pyroclastic surge and fall deposits of Firiplaka. The section includes massive accretionary lapilli-rich layers (AL), a pumice lapilli fall layer (P) and planar bedded ash fall layers (LVS). C The polymictic mud-matrix breccia at Agia Kiriaki beach was generated by phreatic eruptions at nearby vents. The massive breccia contains intact and in situ ancient Roman pots. ${ }^{14} \mathrm{C}$ measurements on the Roman pot fragments (Traineau and Dalabakis 1989) indicated that the phreatic volcanic activity occurred between $200 \mathrm{BC}$ and $200 \mathrm{AD}$
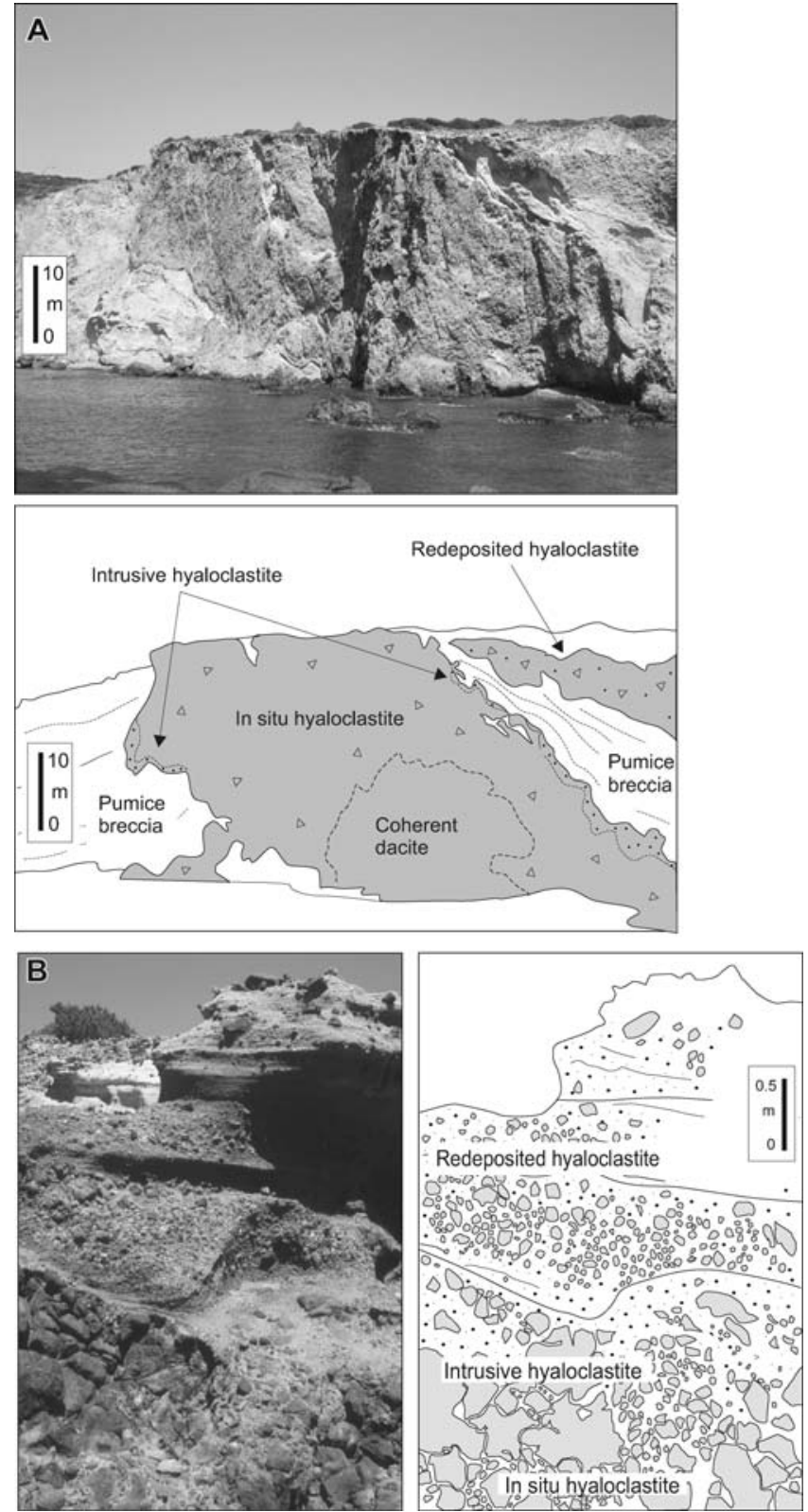

Fig. 8 A A north-south section of the Favas partially extrusive dacite cryptodome, at Triades (Fig. 2), shows the context and contact relationships of the main facies of the dacite facies association. The intrusive facies (coherent dacite, in situ hyloclastite and intrusive hyaloclastite) cross-cut local bedding in the host pumice breccia (white) along highly irregular, discordant contacts. The extrusive facies (redeposited hyaloclastite) is interbedded with pumice breccia. B Upper contact of a submarine dacite dome at Triades. In situ hyaloclastite at the base of the outcrop is gradationally overlain by redeposited hyaloclastite that is stratified

Some facies associations include evidence for the simultaneous existence of both subaerial and submarine depositional settings. One of the best cases is the scoriarich breccia facies association which is restricted to the northeastern part of Milos (Fig. 2) and is volumetrically minor. Facies in this association consist of abundant scoria and large fluidal clasts with quenched margins, resembling the proximal products of weakly explosive, magmatic-volatile-driven strombolian eruptions (Fig. 9A 

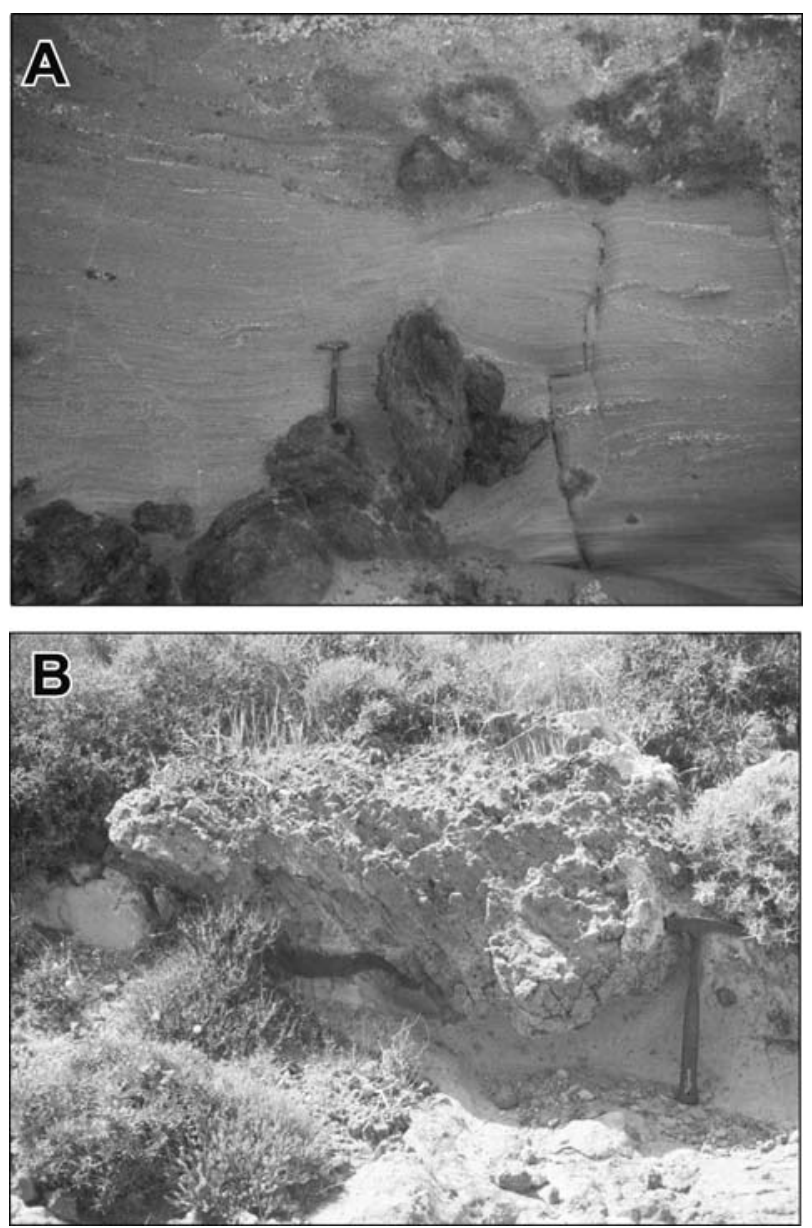

Fig. 9 A Fine scoria sandstone facies. The beds vary in thickness from 5 to $10 \mathrm{~cm}$. Large fluidal clasts are oriented perpendicular to bedding, at Papafragas. B A very coarse fluidal clast at Papafragas

and B). The association conformably overlies thick submarine pumice breccia and is overlain by partly subaerial facies, so the depositional setting was probably close to or above wave base. The bedforms (diffuse stratification, grading and cross stratification) are consistent with deposition from moderate-concentration to high-concentration gravity currents and traction currents. Hence, the vent must have been in even shallower water or subaerial, and in both cases, the eruption column was probably largely subaerial.

\section{Volcano types and architecture}

The volcanic facies architecture of Milos comprises interfingering proximal (near vent), medial (volcano flanks) and distal (volcano margin) facies associations related to five main volcano types (Table 2; Fig. 10A-D): (1) submarine felsic cryptodome-pumice cone volcanoes; (2) submarine dacitic and andesitic lava domes; (3) submarineto-subaerial andesitic scoria cones; (4) partly submerged dacitic and andesitic lava domes and (5) subaerial rhyolitic lava-pumice cone volcanoes.

\section{Submarine felsic cryptodome-pumice cone volcanoes}

Parts of four large submarine felsic cryptodome-pumice cone volcanoes have been identified on Milos, and collectively cover more than $85 \%$ of the total area of the island (Fig. 11A). Their vent areas are centred on Profitis Illias, Bombarda (cf. Rinaldi and Campos Venuti, 2003), Filakopi and Dhemeneghaki (Fig. 11A). The essential elements of these volcanic centres are thick intervals of submarine felsic pumice breccia intruded by compositionally similar, rhyolitic and dacitic cryptodomes and sills (Figs. 10A and $10 \mathrm{C})$. The volcanic centres are broadly circular in plan and each one covers an area of tens of square kilometres. Thicknesses of the proximal sections are typically 300 $350 \mathrm{~m}$ and range up to $450 \mathrm{~m}$. Distal sections are much thinner $(<2 \mathrm{~m})$. The bulk volume of each of these centres is in the order of 4-6 $\mathrm{km}^{3}$ and they represent magma volumes of $\sim 2-3 \mathrm{~km}^{3}$. These volcanoes are similar in style to subaqueous rhyolitic dome-intrusion-tuff volcanoes described by Horikoshi (1969), Cas et al. (1990), Allen et al. (1996) and Ayres and Peloquin (2000).

The proximal parts of the felsic cryptodome-pumice cone volcanoes on Milos are characterised by very thick sections of felsic pumice breccia intruded by a series of small-volume cryptodomes and sills, comprising aphyric or weakly quartz-feldspar \pm biotite-phyric rhyolite and dacite. Single intrusions have lateral extents less than $1.2 \mathrm{~km}$, although groups of close-spaced intrusions cover areas of several square kilometres, such as in the Profitis Illias area (Fig. 2). Contacts of the intrusions are typically defined by intrusive hyaloclastite, indicating that they were emplaced into a host unit that was wet and poorly consolidated (e.g. Snyder and Fraser 1963; Hanson and Wilson 1993; Goto and McPhie 1998; Stewart and McPhie 2003). Lateral facies changes away from the proximal area mainly involve decreases in the volume of intrusions and in the thickness of pumice breccia. Single beds of pumice breccia also decrease in thickness and grain size outwards towards the distal zones. The abundance of interbedded graded sandstone and thickly bedded to laminated mudstone, and of distal facies from other volcanoes also increases outwards (Fig. 11B).

There are two main types of proximal to medial pumice breccia: (1) very thick (tens of metres), massive or diffusely stratified rhyolitic to dacitic pumice breccia; this facies consists of pyroclasts transported and deposited by watersupported gravity currents; and (2) very thick (up to $20 \mathrm{~m}$ ), tabular beds of well sorted, reversely graded, coarse (up to $6.5 \mathrm{~m}$ ) pumice clasts in grain-to-grain contact and set in a much finer $(<1 \mathrm{~mm}-2 \mathrm{~cm})$, pumiceous matrix. The coarse pumice clasts settled from suspension and the framework was progressively infilled by fine pumice clasts and watersettled ash (Stewart and McPhie 2004). This type of pumice breccia is a variety of water-settled fall deposit.

The felsic cryptodome-pumice cone volcanoes were generated by initial, magmatic-volatile-driven explosive eruptions that formed thick submarine deposits of pumice breccia deposits. Later degassed magmas intruded the breccia pile, forming cryptodomes and sills in and around 


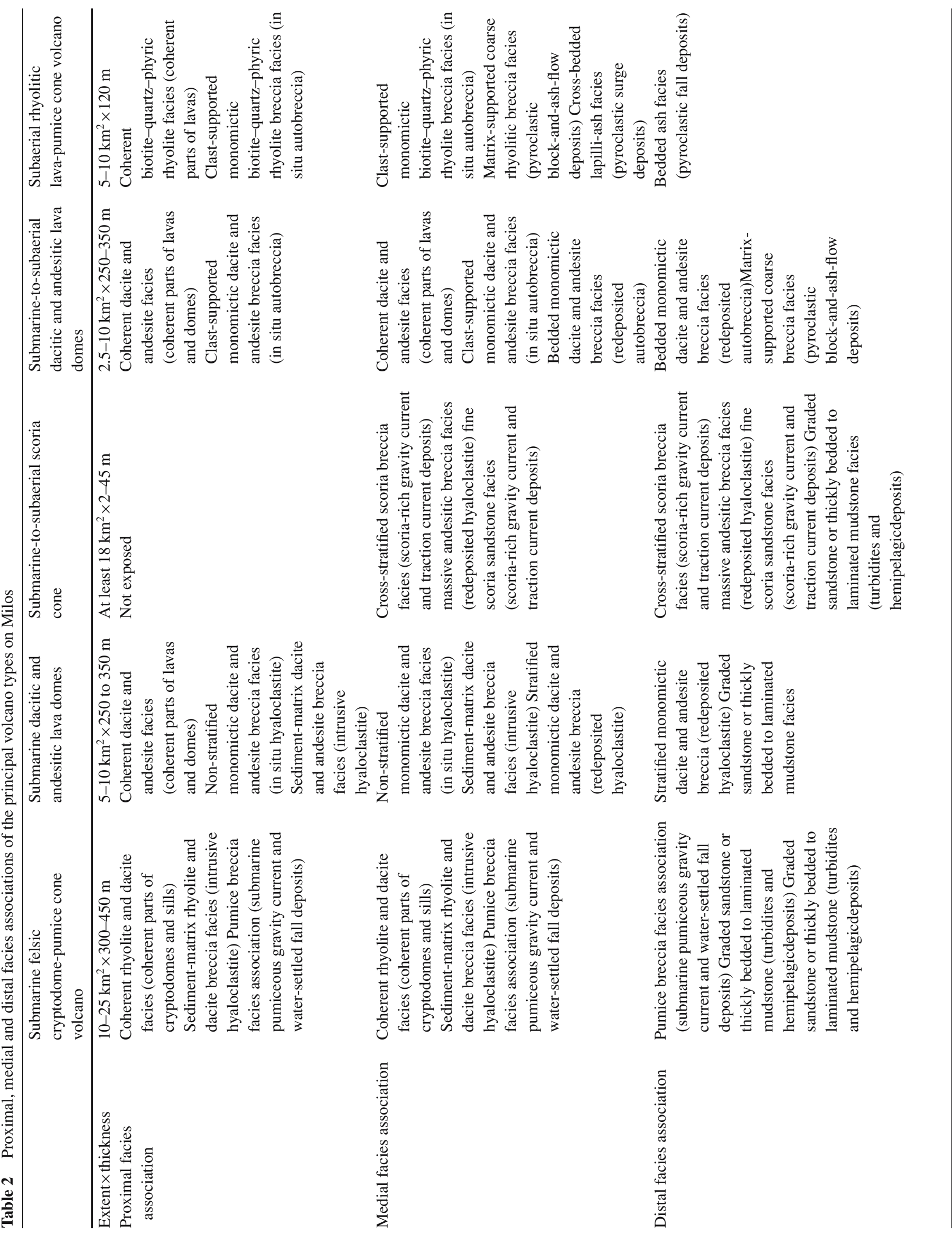


the former vent areas. These volcanoes are interpreted to have been entirely submarine. However, given the relatively shallow-water depositional setting, it is plausible that rapid accumulation of pyroclastic units resulted in the net growth toward sea level and that high-level intrusion of cryptodomes caused up-doming of the pumice breccia pile (cf. Minakami et al. 1951). Therefore, it is possible that some of the volcanoes grew to sea level and breached the air-water interface.

Submarine dacitic and andesitic lava domes

Submarine dacitic and andesitic lava dome volcanoes cover approximately $10 \%$ of the island, and range from 2.5 to $10 \mathrm{~km}$ in diameter and $250-350 \mathrm{~m}$ in thickness in the proximal parts. Several volcanic centres of this type are inferred, but those in the Triades area of northwestern Milos are the best exposed (Fig. 12A). These domes are dominated by the products of submarine, effusive, dacitic and andesitic eruptions and are composed of variable amounts of coherent dacite or andesite and in situ and redeposited hyaloclastite (Table 2).

The dacitic and andesitic lava domes on Milos form thick (up to $300 \mathrm{~m}$ ), high-aspect-ratio units similar to lava domes in other modern and ancient submarine settings (cf. Horikoshi 1969; Yamagishi and Dimroth 1985, 1987; Yamagishi 1991; Yamagishi and Goto 1992; Fig. 12A). They are strongly constructional and characterised by a broadly concentric internal structure, consisting of a massive coherent core, flow-banded outer zone, in situ brecciated margin and an enveloping carapace of hyaloclastite (Fig. 12B; Fig. 10A - $\operatorname{logs} \mathrm{A}, \mathrm{B}$ and D). The coherent core is volumetrically dominant, uniformly microcrystalline and columnar jointed. A perlitic or flow-banded outer zone $30-40 \mathrm{~m}$ thick commonly surrounds the massive coherent core. Flow bands are approximately parallel to the dome margin. The outer zone is overlain by or enclosed in closely fractured dacite or andesite breccia and hyaloclastite produced by quench fragmentation of the margins of the dome. Where exposed, the basal contacts of the domes consist of intrusive hyaloclastite and the underlying sediments are locally deformed, implying that the domes flowed over and locally burrowed into wet, unconsolidated sediments.

The medial to distal parts of these volcanoes on Milos are characterised by stratified dacitic or andesitic breccia (Fig. 12B), generated by down-slope remobilisation of unconsolidated hyaloclastite and autobreccia. These breccias become progressively thinner and finer, and bed thickness

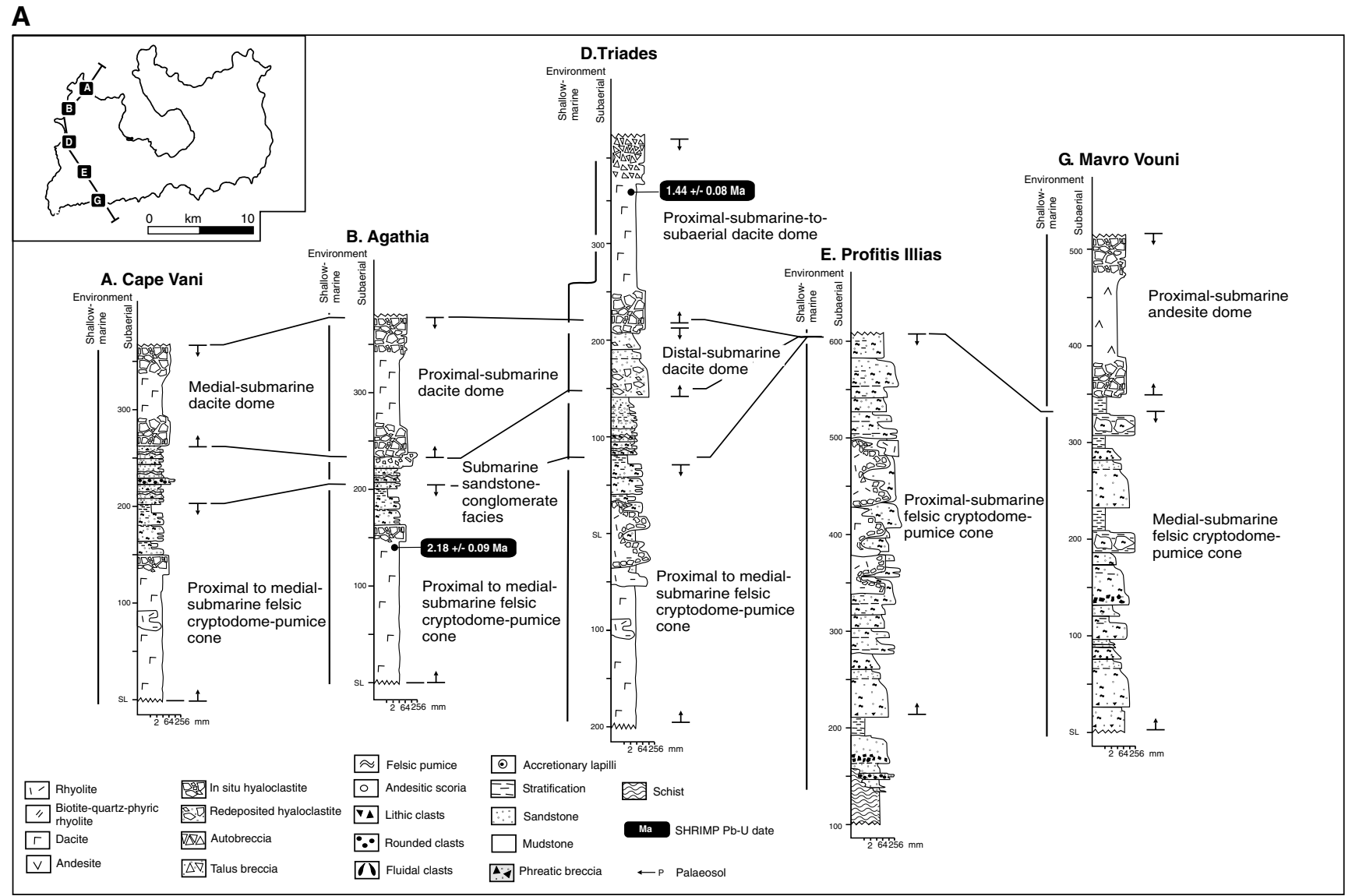

Fig. 10 Stratigraphic columns for Milos along four transects: A, western transect; $\mathbf{B}$, southern transect; $\mathbf{C}$, northern transect; $\mathbf{D}$, eastern transect, showing facies, contact relationships, and interpreted

volcano types and depositional environments. Thicknesses shown are calculated or measured true thickness. Locations of the columns are shown on the inset map. SL represents current sea level 
decreases over relatively short (tens to hundreds of metres) distances from source.

Submarine-to-subaerial scoria cone

A variety of andesitic, scoria-rich, clastic facies exposed in northeastern Milos are part of a scoria cone that may have been partly emergent. The scoria-rich deposits consist of abundant scoria and large fluidal clasts with quenched margins (Fig. 9), resembling the primary and redeposited products of weakly explosive, strombolian eruptions (cf. Staudigel and Schmincke 1984; Cas et al. 1989; Houghton and Landis 1989; Dolozi and Ayres 1991; Kano 1998). They conformably overlie thick submarine pumice breccia and are overlain by partly subaerial facies. The bedforms (diffuse stratification, grading and cross stratification) are consistent with deposition from moderate-concentration to high-concentration gravity currents and traction currents, so the depositional setting was probably close to or above wave base. Hence, the vent must have been in even shallower water or subaerial, and in either case, the eruption column was probably largely subaerial.

Remnants of the scoria cone cover an area of $18 \mathrm{~km}^{2}$. The thickest (up to $45 \mathrm{~m}$ ) and coarsest sections occur at Pollonia (Fig. 10C $-\log N$ ). Single units near the eastern limits of outcrop are thinner $(\sim 2 \mathrm{~m})$ and finer than those near
Pollonia. Feeder dykes and coarse agglutinate-like deposits expected to mark near-vent positions (Houghton and Landis 1989; Smith and Batiza 1989) are absent, suggesting that the most proximal parts are not exposed onshore. Hence, all the preserved sections of the andesitic scoria cone are probably medial and distal.

Partly submerged dacitic and andesitic domes

Partly submerged dacitic and andesitic dome volcanoes are restricted to the Kontaro, Korakia and Krotiraki areas, and Arkadies Island (Fig. 13A). They cover $<5 \%$ of Milos and range from 2.5 to $10 \mathrm{~km}$ in diameter and $250-350 \mathrm{~m}$ in thickness in the proximal parts. The proximal parts of these volcanoes are similar to felsic and intermediate lava domes in modern subaerial volcanic successions (cf. Huppert et al. 1982; Swanson and Holcomb 1990). They are characterised by thick (up to $250 \mathrm{~m}$ ), high-aspect-ratio intervals of coherent dacite and andesite (Fig. 13A). Single domes comprise a massive coherent core, flow-banded rind and an envelope or carapace of in situ autobreccia.

Away from the proximal area, the partly submerged setting and differences from subaerial domes are apparent. In the medial sections, there are marked decreases in the proportion of coherent lava and the thickness of in situ

B

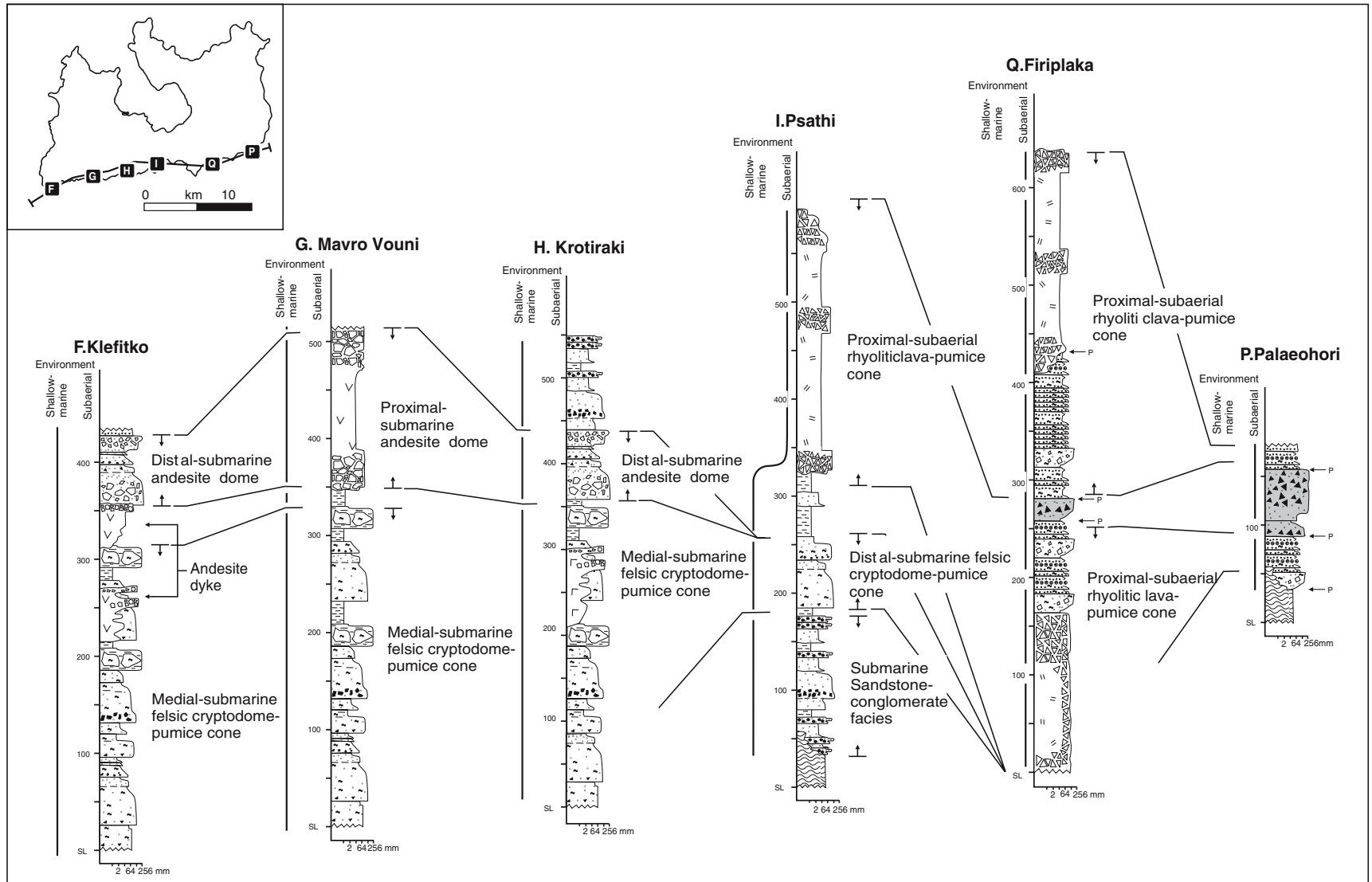

Fig. 10 Continued 
autobreccia. These sections are characterised by abundant bedded, monomictic dacitic and andesitic breccia that represent talus aprons composed of redeposited autobreccia. The presence of graded sandstone beds intercalated with the talus breccia indicates that the breccias were deposited in shallow marine environments adjacent to emergent domes.

\section{Subaerial rhyolitic lava-pumice cone volcanoes}

Three large subaerial rhyolitic lava-pumice cone volcanoes are present on Milos, at Trachilas in the north, Firiplaka in the south and Halepa on the southern coast. They are broadly circular in plan and have diameters in the range of 5-8 km. The proximal zones of these volcanic centres are about $120 \mathrm{~m}$ thick, and the distal parts are much thinner (several metres). Detailed study of the Firiplaka centre by Campos Venuti and Rossi (1996) indicated that initial explosive eruptions were phreatic and evolved to a conebuilding phreatomagmatic episode represented by surge deposits. Later eruptions produced ash fall deposits and lavas.

The proximal parts of the subaerial rhyolitic lavapumice cone volcanoes on Milos are dominated by thick $(\sim 200 \mathrm{~m})$ pyroclastic deposits and small-volume, biotite-quartz-phyric rhyolite lavas up to $100 \mathrm{~m}$ in thickness, and cover several square kilometres. The lavas display tabular geometries similar to many other felsic lavas in modern subaerial environments (cf. Fink 1980). They are strongly constructional and characterised by a broadly concentric internal structure, consisting of a massive coherent core, an outer flow-banded zone and a brecciated margin composed of autobreccia and talus breccia.

There are two main pyroclastic facies in the proximal to medial sections: (1) very thick (tens of metres) intervals of poorly sorted, cross-bedded lapilli-ash (pyroclastic surge deposits); and (2) thin $(<1 \mathrm{~m})$ intervals of bedded ash (fall deposits). Away from the proximal area, the lavas become thinner (15-20 m) and the pyroclastic facies become thinner. Distal pyroclastic facies are dominated by thin, bedded ash fall deposits.

\section{Thickness variations}

The volcanic and sedimentary succession of Milos varies in thickness from a minimum of tens of metres in the Paliochori area (Fig. 2) in the eastern part of the island, up to

\section{C}

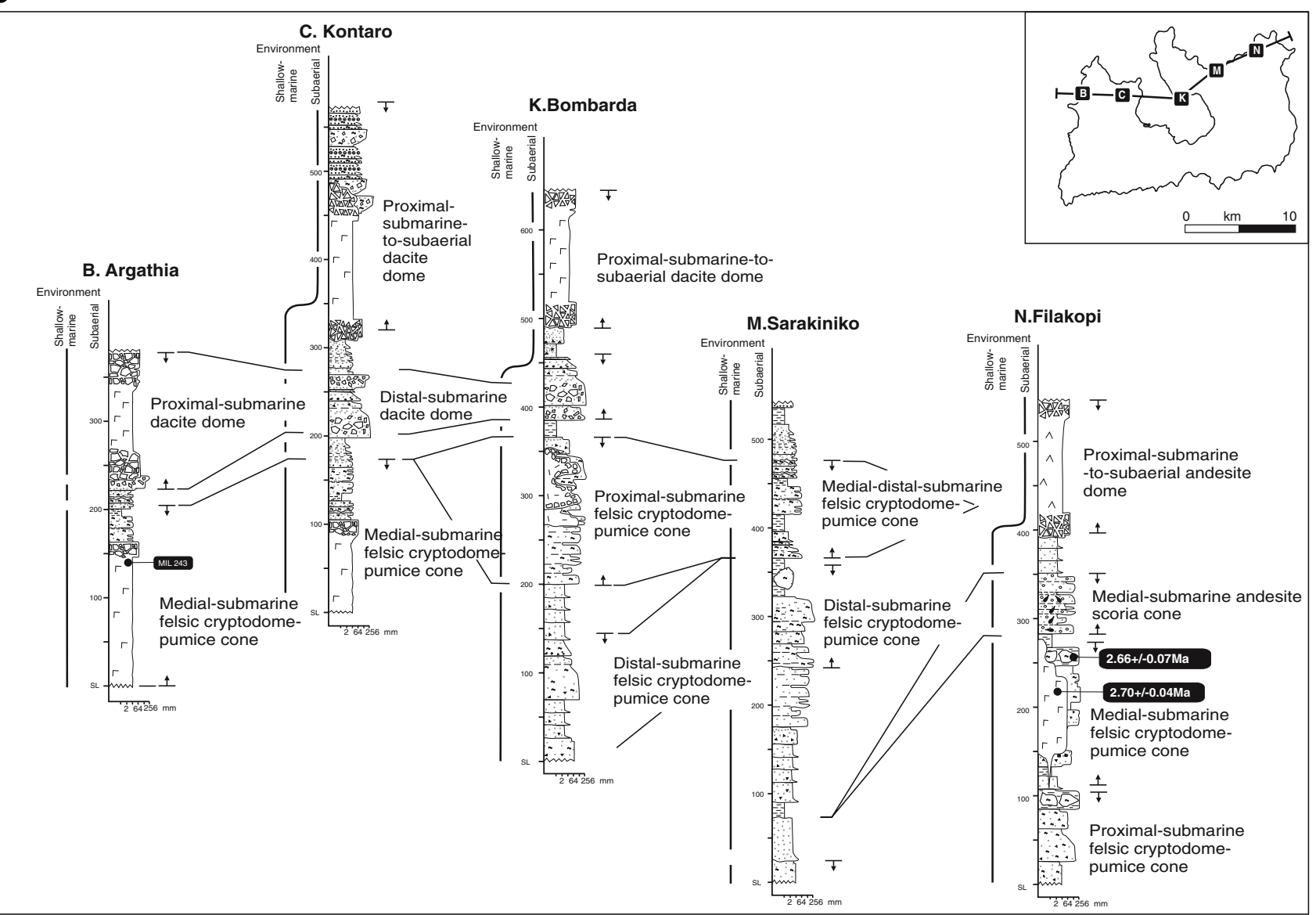

Fig. 10 Continued 
$\sim 700 \mathrm{~m}$ in the northeastern part of the island (Fig. 10A $-\log$ E). The variations across the island are directly attributed to a combination of pre-volcanic palaeogeography, synvolcanic faulting and constructional volcanism. The western and northeastern sectors of Milos are dominated by a laterally extensive succession of submarine pumice breccia and sedimentary facies more than $300 \mathrm{~m}$ thick. This part of the succession displays the least internal heterogeneity (Fig. 10B - log E) but thins towards and is absent from the southeastern sector of the island, east of Psathi (Fig. 10B - $\log$ I) and south of Dhemeneghakia (Fig. 10B $\log \mathrm{P})$. This thickness trend suggests that the southeastern part of the island was a topographic high (possibly shoaling or subaerial) throughout most of the Late Pliocene -Pleistocene, and therefore receiving relatively little sediment.

Syn-volcanic normal faults are well exposed in basal parts of the succession, some of which have displacements up to several hundred metres (Fytikas et al. 1986). Such faults must have been important in shaping topography and creating depositional basins, especially in the western and northeastern sectors of the island, where the volcanic succession is thickest (up to $700 \mathrm{~m}$ ).

\section{Age of volcanism}

A variety of dating techniques has been applied to the volcanic units on Milos: K-Ar radiometric dating of biotite and amphibole (Fytikas et al. 1976; Angelier et al. 1977; Fytikas et al. 1986), fission track dating of felsic glasses (Bigazzi and Radi 1981), ${ }^{14} \mathrm{C}$ measurements on Roman pot fragments (Traineau and Dalabakis 1989; Principe et al. 2002, 2003), and sensitive high-resolution ion microprobe (SHRIMP II) analyses of ${ }^{206} \mathrm{~Pb} /{ }^{238} \mathrm{U}$ in zircons (Electronic Supplemntary material; Table 3). The results indicate that volcanic activity on Milos began during the Late Pliocene ( $\sim 3 \mathrm{Ma})$ and has continued to relatively recent times (200 $\mathrm{BC}$ to $200 \mathrm{AD}$ ).

The submarine pumice breccias at the base of the succession are interbedded with sedimentary units that contain Late Pliocene marine fossils (cf. Fytikas et al. 1977). A $\mathrm{K}-\mathrm{Ar}$ date on a non-juvenile rhyolite clast in submarine pumice breccia suggests a maximum age of $3.08 \pm 0.14 \mathrm{Ma}$ (Fytikas et al. 1986). SHRIMP U-Pb dating of zircon in a juvenile pumice clast in the Filakopi Pumice Breccia (Stewart and McPhie 2004) provides an upper age limit for the submarine pumice breccias at about $2.66 \pm 0.07 \mathrm{Ma}$

D

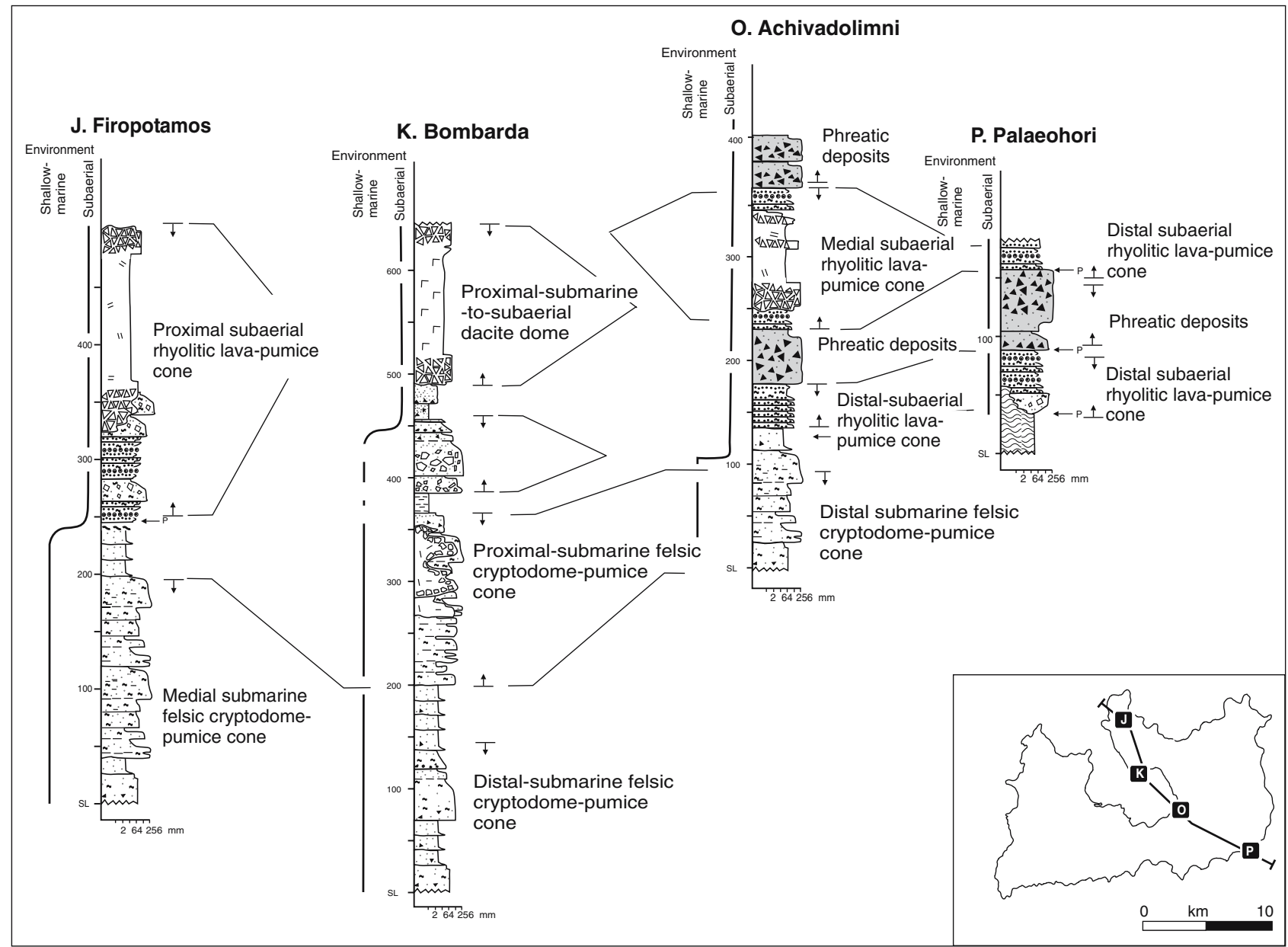

Fig. 10 Continued 
Table 3 A summary of $\mathrm{SHRIMP} \mathrm{U}-\mathrm{Pb}$ ages. Location of samples on Fig. 2 and raw data in Appendix 1

\begin{tabular}{lll}
\hline Sample number & Sample description & Crystallisation age (Ma) \\
\hline MIL 130 & Coherent dacite facies, Triades & $1.44 \pm 0.08$ \\
MIL 243 & Coherent dacite facies, Triades & $2.18 \pm 0.09$ \\
MIL 343 & Coherent dacite facies (Kalogeros cryptodome) & $2.70 \pm 0.04$ \\
MIL 365 & Pumice breccia facies (Filakopi Pumice Breccia) & $2.66 \pm 0.07$ \\
\hline
\end{tabular}

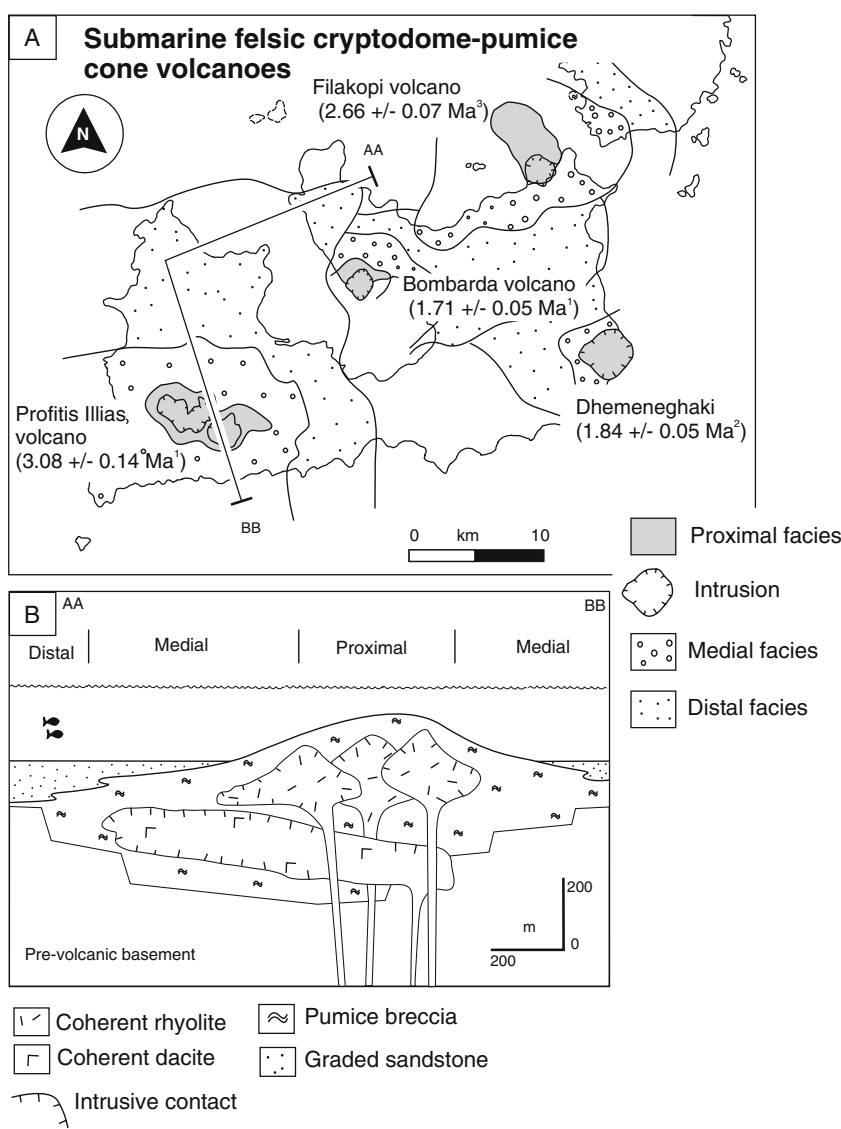

Fig. 11 Submarine felsic cryptodome-pumice cone volcanoes. A Map showing the proximal, medial and distal parts of the four main submarine felsic cryptodome-pumice cone volcanoes on Milos. B Facies model for submarine felsic cryptodome-pumice cone volcanoes on Milos. The schematic cross-section of the Profitis Illias volcano displays the spatial distribution of facies and internal structure. Location of cross-section on Fig. 11A. Age data from 1 Fytikas et al. (1986); 2 Bigazzi and Radi (1981); 3 This study (see Table 3)

(Table 3). SHRIMP U-Pb in zircon dating of the Kalogeros dacitic cryptodome (Fig. 10C $-\log \mathrm{N}$ ) on the northern coast, has given an age of $2.70 \pm 0.04$ Ma. Taking analytical error into consideration, the Kalogeros cryptodome is approximately contemporaneous with the Filakopi Pumice Breccia, and the two units together form one of the four main submarine felsic cryptodome-pumice cone volcanoes recognised. SHRIMP U-Pb in zircon dating of a dacite lava at Triades on the western coast (Fig. 2) has yielded an age of $2.18 \pm 0.09 \mathrm{Ma}$.

The subaerial part of the succession probably begins at $1.44 \pm 0.08 \mathrm{Ma}$ (Fig. 14) which is the SHRIMP U-Pb in zircon date obtained on one of the oldest subaerial dacite domes. The subaerial Halepa rhyolite lava on the southern coast of Milos, and the Firiplaka and Trachilas rhyolitic centres are all younger again. The Halepa rhyolite has been dated at $0.95 \pm 0.08 \mathrm{Ma}$ (Fytikas et al. 1986; K-Ar on biotite). K-Ar dates for the Firiplaka volcanic centre range from $0.48 \pm 0.05$ to $0.09 \pm 0.02 \mathrm{Ma}$ (Fytikas et al. 1976; Fytikas et al. 1986). The single K-Ar date of $0.37 \pm 0.09$ Ma (Fytikas et al. 1986) from the Trachilas volcanic centre falls within that range.${ }^{14} \mathrm{C}$ dating of Roman pot fragments contained within the phreatic deposits in the Agia Kiriaki area indicate an age $200 \mathrm{BC}$ to $200 \mathrm{AD}$ (Traineau and Dalabakis 1989), which is consistent with archaeological findings (Renfrew and Wagstaff 1982).

Although the geochronological data are far from comprehensive, this compilation shows a very clear pattern of felsic eruptions having occurred on Milos at more or less regular intervals for the past 3 million years. There are no prolongued breaks nor are there periods of particularly intense volcanism. It appears that eruptions have taken place every 100,000 years or less, and no repose period has been longer than a few hundred thousand years. The pattern is also consistent with field relationships-we have found no island-wide disconformities, palaeosols or reworked intervals that might be records of an extended break in volcanic aggradation.

\section{Palaeogeographic reconstruction and evolution of Milos Island}

In this section, constraints on the Eocene to Miocene setting of volcanic activity are reviewed, and followed by a discussion of the inferred Pliocene-Pleistocene palaeogeography (Fig. 14).

Mesozoic basement and Neogene sedimentary formations

In the northern, southern and western sectors of Milos, the Mesozoic metamorphic rocks are unconformably overlain by the Neogene sedimentary group. The Neogene sedimentary group is exposed only to the west of the Firiplaka Fault (Fig. 2). Hence, the Mesozoic metamorphic rocks of the southeastern sector of the island were most likely topographically high (possibly shoaling or subaerial), therefore reducing Neogene sedimentation in this area. Also, the Neogene sedimentary group has mixed provenance that includes rocks of the Mesozoic basement, implying that the basement was exposed to erosion during the Neogene. The undulating topography exhibited by the unconformity with the basement suggests that the palaeogeography during the 
Fig. 12 Submarine dacitic and andesitic lava domes. A Map showing the proximal, medial and distal parts of the main submarine dacitic and andesitic lava domes on Milos. B Facies model for submarine dacitic and andesitic lava dome volcanoes on Milos, based on a schematic cross-section of the Triades domes. Location of cross section on Fig. 12A. Age data from 1 Fytikas et al. (1986); 2 Angelier et al. (1977); 3 This study (see Table 3)
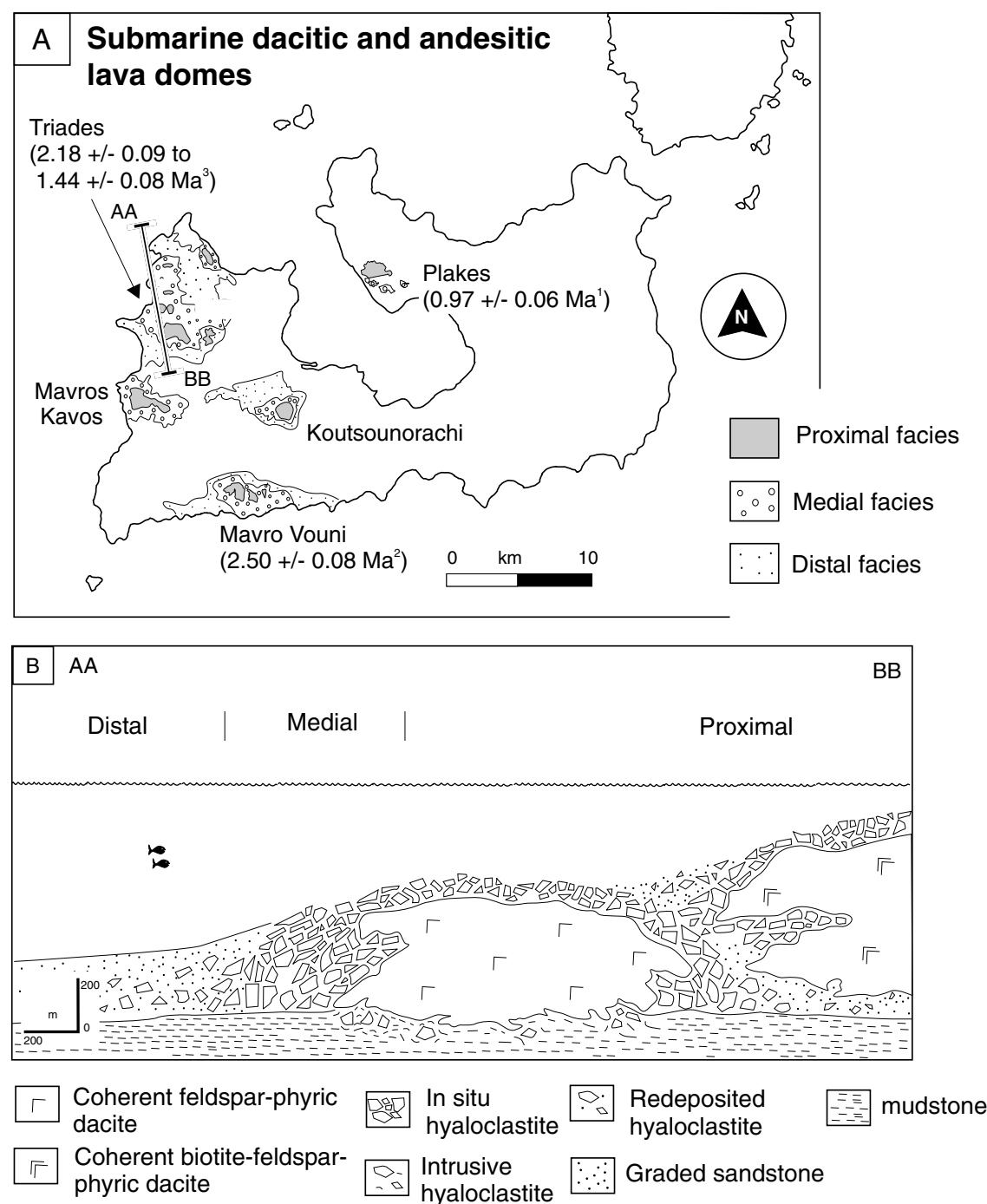

Neogene comprised a small island or perhaps a group of small islands in the southeast, flanked by shallow- to deepmarine areas.

Late Pliocene - Pleistocene volcanic evolution

The onset of explosive felsic volcanism $(3.08 \pm 0.14 \mathrm{Ma}$, Fytikas et al. 1986) generated thick $(\sim 300 \mathrm{~m})$ intervals of pumice breccia (1 in Fig. 14A). Bioturbated and fossiliferous mudstone intervals interbedded with pumice breccia near the base of the volcanic succession indicate that the depositional setting was relatively shallow submarine. The presence of tabular, massive to graded beds typical of deposits from gravity currents, and the absence of sedimentary structures indicative of wave action (e.g. symmetic ripples or hummocky cross-stratification) are consistent with a setting below wave base. The source vents would have been shallower than the depositional setting and hence, were probably in water perhaps only a few hundred metres deep. Waterlogged pumice clasts, shards and crystals were transported and deposited by water- supported gravity currents and also settled from suspension. The initial gravity currents were overloaded with dense lithic clasts but later currents were pumiceous, reflecting open-vent explosivity and rapid waterlogging of abundant hot, pumice lapilli (Stewart and McPhie 2004).

Rhyolitic and dacitic cryptodomes (e.g. Kalogeros Dacite, Stewart and McPhie 2003) and sills subsequently intruded the thick, poorly consolidated pumice pile ( 2 in Fig. 14A). The intrusion of cryptodomes and sills disrupted the pumice breccia succession, and in many cases, presumably domed the sea floor. Parts of the original volcanic centres that were emplaced above wave base were probably easily eroded. Some historical, shallow-marine rhyolitic eruptions formed ephemeral islands that underwent several cycles of construction and degradation. For example, the 1953-57 submarine eruptions of Tuluman volcano repeatedly formed islands subject to erosion and submergence (Reynolds et al. 1980).

Andesite dykes are volumetrically minor and restricted in occurrence to the margins of the Profitis Illias felsic cryptodome-pumice cone volcano (3 in Fig. 14A). The 
Fig. 13 Partly submerged dacitic and andesitic domes. A Map showing the proximal, medial and distal parts of partly submerged dacitic and andesitic lava domes on Milos. B Facies model for

submarine-to-subaerial dacitic and andesitic domes on Milos, based on a schematic cross section of the Krotiraki volcano. Location of cross-section on Fig. 13A. Age data from 1 Fytikas et al. (1986)
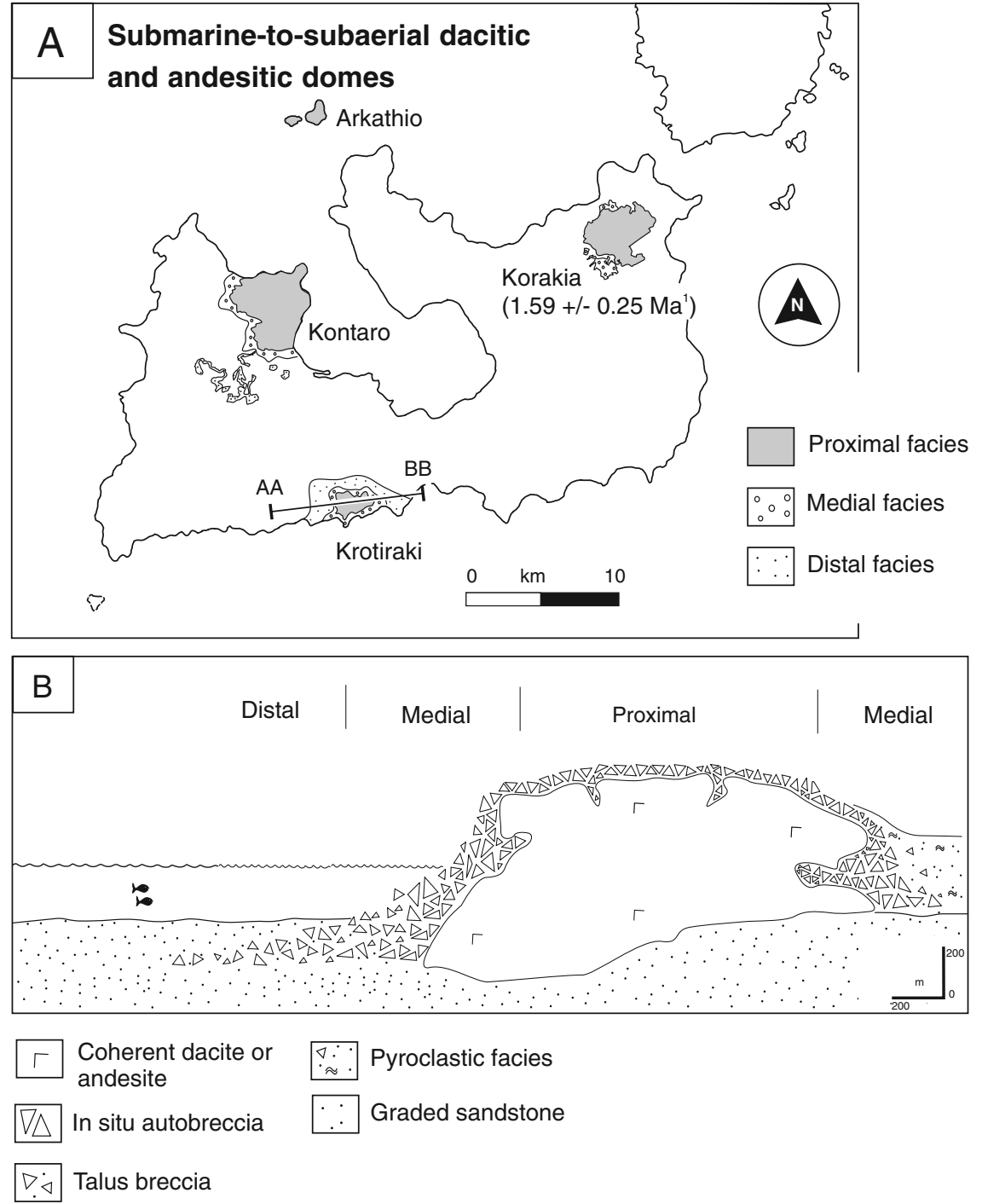

dykes intruded the pumice breccia and lower part of the overlying sandstone-conglomerate facies.

The palaeogeography generated by the initial volcanism comprised low-angle fans of pumice breccia around rhyolitic-dacitic intrusion centres rising gently from the sea floor. Depositional environments of the proximal and medial parts of these cryptodome-pumice cone volcanoes were mainly shallow marine, whereas the medial to distal settings were mainly shallow to deeper marine. It is likely that accumulation of the main pumiceous units resulted in net growth towards sea level, but as there are no erosional disconformities or subaerial facies in this part of the succession, aggradation must have been countered by subsidence.

The dominantly rhyolitic explosive and intrusive activity was followed by widespread effusive volcanism that formed numerous dacitic and andesitic lavas and domes on the sea floor (1 in Fig. 14B). Autoclastic facies, mainly hyaloclastite, are intercalated with graded sandstone and thickly bedded to laminated mudstone and indicate that the initial depositional setting was shallow marine (below wave base). At some locations, for example, between Triades and Agathia, high-aspect-ratio dacitic lavas overlap without intervening sedimentary facies ( 2 in Fig. 14B). The lavas and domes were constructional and formed local topographic highs rising above the sea floor to become volcanic islands.

In the northeastern part of the island, weakly explosive, magmatic-volatile-driven strombolian eruptions built an ephemeral scoria cone subject to collapse and resedimentation, delivering scoria lapilli and fluidal bombs into deeper-water flanking environments. Given the relatively shallow sea water setting, the edifice may have shoaled (3 in Fig. 14B).

Elevated sea floor volcanic centres (4 in Fig. 14B) were separated by low-lying regions where stratigraphically equivalent sand and mud were deposited. The sandstone and mudstone units are dominated by volcanic quartz and feldspar, pumice and glass shards, suggesting a largely felsic volcanic source. The remaining components are clearly non-volcanic (detrital mica and polycrystalline quartz) and imply input from basement sources. Graded, very thick 
A
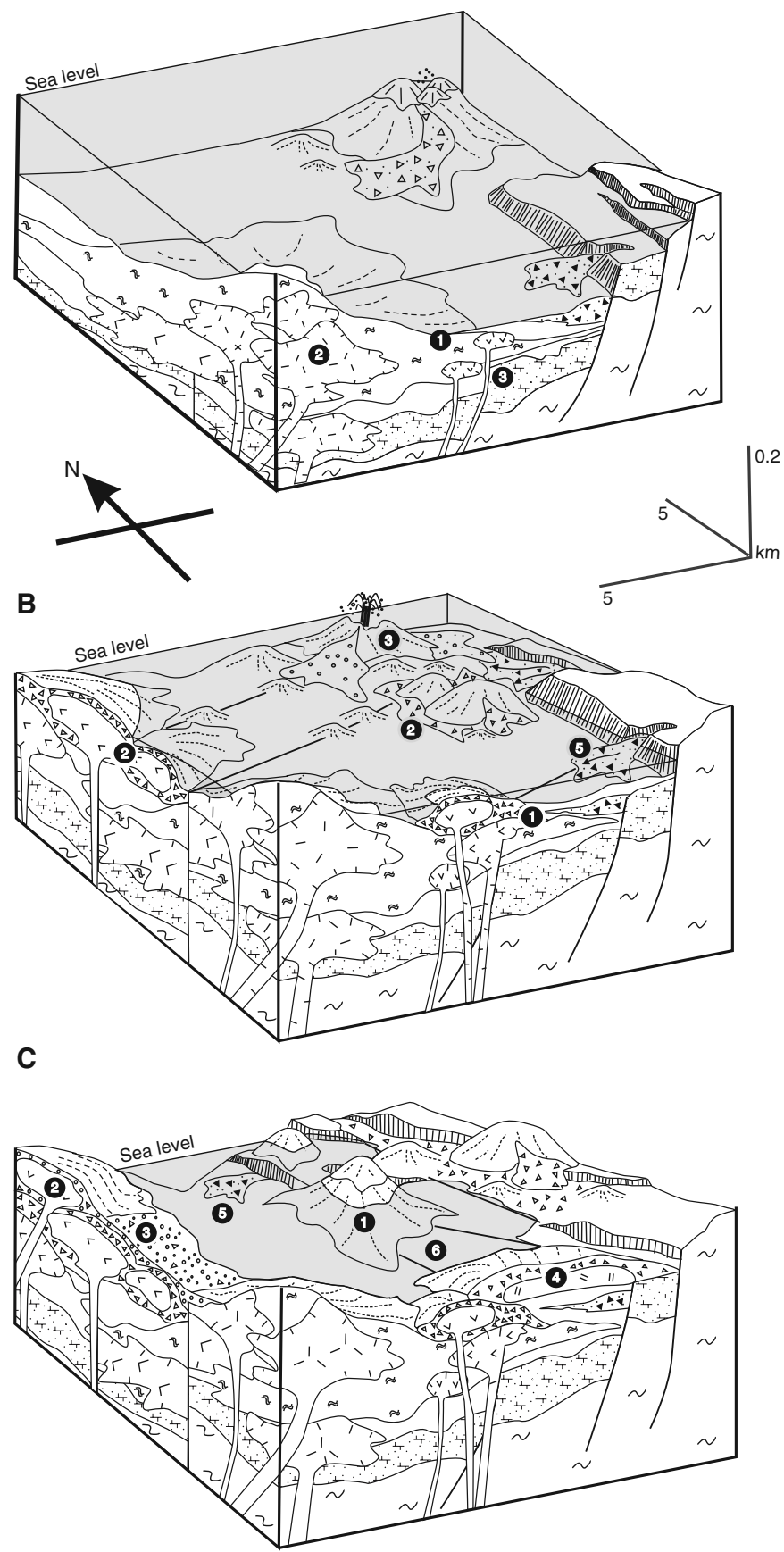

Fig. 14 Schematic palaeogeographic reconstruction and facies architecture of Milos; A Late Pliocene (3-2.5 Ma). 1-Thick submarine pumice breccia facies generated by felsic explosive volcanism; 2Rhyolitic and dacitic cryptodomes and sills; 3-Basaltic andesite intrusions. B Late Pliocene-Early Pleistocene (2.5-1.5 Ma). 1-Mainly submarine, dacitic and andesitic lavas and domes; 2-Redeposited autobreccia and hyaloclastite associated with the growth of dacitic and andesitic domes; 3-Construction of a submarine andesitic scoria cone; 5-Post-eruptive basement-derived polymictic-lithic breccia. C Early Pleistocene (1.5-0.5 Ma). 1-Construction of a submarine felsic
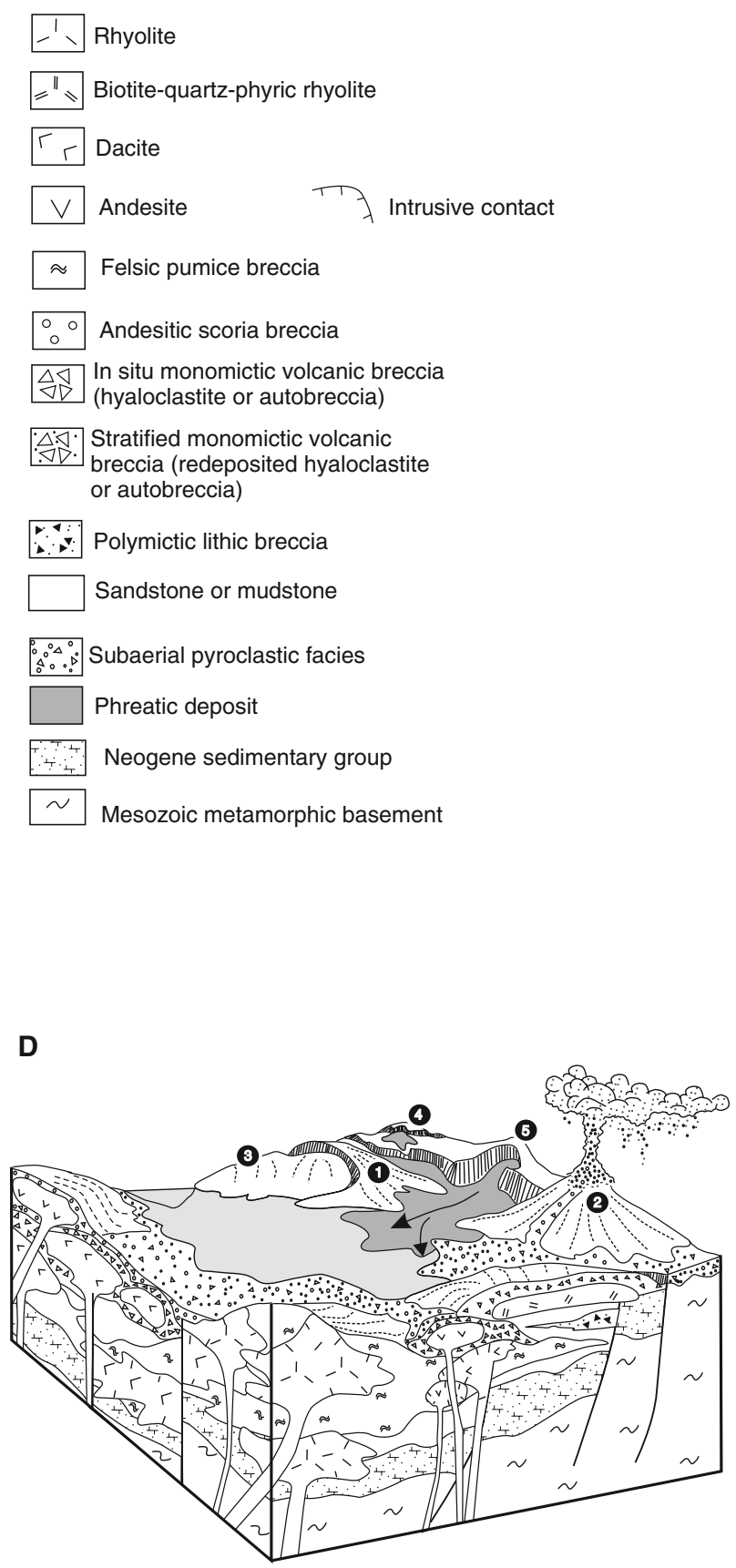

dome-cryptodome-pumice cone volcano; 2- Submarine-to-subaerial dacitic and andesitic lavas and domes; 3-Syn-eruptive deposition of block and ash deposits; 4-Rhyolitic lava and associated autoclastic breccia; 5-Local influx of turbidites composed of detritus eroded from dormant volcanic centres; 6-Syn-volcanic faults. D Late Pleistocene $(0.5 \mathrm{Ma})$ to present. 1 and 2-Construction of two subaerial rhyolitic pumice cone volcanoes at Trachilas and Firiplaka respectively; 3-Subaerial rhyolitic lava and associated autobreccia; 4-Small subaerial phreatic craters; 5-Basement-derived, subaerial, mass-flow deposit 
beds of polymictic breccia-conglomerate facies contain abundant rounded rhyolitic and dacitic clasts that indicate reworking in high-energy, subaerial to shallow marine, environments (above storm wave base), prior to deposition below wave base. In other sections, cross-bedded sandstone indicates that the depositional setting was most likely above wave base. Hence, depositional environments ranged from below to above wave base, and source areas were in very shallow water and/or subaerial.

The next volcanic activity constructed the Bombarda cryptodome-pumice cone volcano in the central part of the island (1 in Fig. 14C). Explosive rhyolitic eruptions generated thick, submarine, pumiceous volcaniclastic facies. Rinaldi and Campos Venuti (2003) suggested that the pumice breccia units were deposited in sea water about $50 \mathrm{~m}$ deep but that parts of the volcanic centre were in shallow water or subaerial. The Bombarda rhyolite dome intrudes the most proximal volcaniclastic facies and probably occupies the vent.

Eruption of numerous dacitic and andesitic lavas and domes (2 in Fig. 14C) effectively culminated in emergence and established much of the present-day outline of the island. In situ pyroclastic facies (block-and-ash flow and surge deposits) and palaeosols associated with the domes delineate the areas that were subaerial (3 in Fig. 14C). The large, biotite-quartz-phyric Halepa rhyolite lava was emplaced in the central part of the island (4 in Fig. 14C).

Thick $(5-70 \mathrm{~m})$ and laterally restricted intervals of graded sandstone, pumice breccia, polymictic brecciaconglomerate and fossiliferous mudstone indicate that the central part of Milos was still partly occupied by a relatively low-lying depression (Gulf of Milos), possibly open to the ocean in the west (5 and 6 in Fig. 14C). Sedimentation was dominated by the primary and reworked products of felsic explosive eruptions and the depositional setting was shallow marine.

Extensive subaerial emergence was achieved by the beginning of the Pleistocene $(1.44 \pm 0.08 \mathrm{Ma})$ in response to a combination of volcanic constructional processes. Since then, the two rhyolitic volcanic centres of Trachilas (1 in Fig. 14D) and Firiplaka (2 in Fig. 14D) have formed. Both centres consist of broad (up to $2.5 \mathrm{~km}$ in diameter), relatively high (up to $200 \mathrm{~m}$ ), circular pumice cones generated by a combination of phreatic and phreatomagmatic eruptions (Campos Venuti and Rossi 1996), and relatively extensive, thick, biotite-quartz-phyric rhyolitic lavas (3 in Fig. 14D). The lavas disrupted the outer pumice cone and flowed into the Gulf of Milos.

Over much of the northern and southern parts of Milos, subaerial rhyolitic volcanism was accompanied by phreatic activity. Small steam-driven explosions formed numerous overlapping craters in the northern part of the Zefiria Graben (4 in Fig. 14D). Pyroclastic breccias containing abundant altered clasts suggest that some explosions were caused by pressure variations within the upper $300 \mathrm{~m}$ of an active hydrothermal system (Fytikas et al. 1989). Principe et al. (2002) speculated that this phreatic activity originated in part from the failure of the metamorphic base- ment once located offshore from the present-day basement outcrops on the coast at Paliochori (Fig. 2) and generated lithic breccia composed mainly of variably altered metamorphic basement clasts. Phreatic activity has continued to very recent times (200 BC to $200 \mathrm{AD}$; Traineau and Dalabakis 1989) and coincided with human habitation of the island.

\section{Conclusions}

The Upper Pliocene - Pleistocene volcanic succession of Milos was constructed on Mesozoic metamorphic basement and Neogene sedimentary rocks. A compilation of radiometric dates indicates that the volcanic succession formed within about 3 million years and there is neither field nor geochronological evidence for any significant breaks. Depositional environments evolved from below to above wave base to subaerial in most areas, except at the southeastern sector of the island where pre-existing subaerial environments persisted. The volcanic facies and facies associations comprise the intercalated products of shallow intrusive events, effusive and explosive eruptions and post-eruptive resedimentation.

The present island consists of the products of multiple, mainly felsic volcanic centres, involving:

1. growth of large submarine felsic cryptodome-pumice cone volcanoes broadly synchronous with the formation of epithermal mineralisation (broadly equivalent to the basal pyroclastic series of Fytikas et al. 1986);

2. submarine effusion and intrusion of several dacitic to andesitic lavas and domes, and subaerial emergence associated with small-volume pyroclastic deposits (including units mainly assigned to the complex of domes and lava flows, and the pyroclastic series and lava domes, of Fytakis et al. 1986) and;

3. subaerial explosive eruptions, forming rhyolitic pumicecone volcanoes, followed by rhyolite lavas (rhyolitic complexes of Firiplaka and Trachilas), and accompanied by widespread phreatic activity.

Acknowledgements This study was supported by the Australian Research Council Special Research Centre Program and an Australian Postgraduate Award to ALS. We would like to thank Georges Vougioykalakis, Michael Fytikas, Claudia Principe, Rod Feldtmann and Mirko Rinaldi for valuable discussions in the field. We also thank Don Baker (Royal Gold Inc.) and George Xydous (Silver and Baryte Ore Mining Co. SA.) and the geological staff of Midas SA. for logistic support. Marc Norman is thanked for obtaining SHRIMP data at the Australian National University. Rod Allen, Dick Fiske and Sharon Allen have cast their critical eye over earlier versions of this manuscript, and are all thanked for their constructive comments and discussions. Both David Pyle and Colin Wilson are thanked for their meticulous reviews.

\section{References}

Allen RL (1992) Reconstruction of the tectonic, volcanic and sedimentary setting of strongly deformed $\mathrm{Zn}-\mathrm{Cu}$ massive sulfide deposits at Benambra, Victoria. Econ Geol 87:825-854 
Allen RL, Weihed P, Svenson S-A (1996) Setting of $\mathrm{Zn}-\mathrm{Cu}-\mathrm{Au}-\mathrm{Ag}$ massive sulfide deposits in the evolution and facies architecture of a 1.9 Ga marine volcanic arc, Skellefte district, Sweden. Econ Geol 91:1022-1053

Angelier J, Cantagrel JM, Vilminot JC (1977) Neotectonique cassante et volcanisme plio-quaternaire dans el'arc égéen interne: L'Ile de Milos (Grece). Bull Soc Géol Fr 19:119-121

Ayres LD, Peloquin AS (2000) Subaqueous, Paleoproterozoic, metarhyolite dome-flow-cone complex, Flin Flon greenstone belt, Manitoba, Canada. Precamb Res 101:211-235

Bigazzi G, Radi D (1981) Datazione con trace di fissione per I'identificazione della provenienza dei manufatti di ossidiana. Riv Sci Preist 36:223-250

Bonnichsen B, Kauffman DF (1987) Physical features of rhyolite lava flows in the Snake River Plain volcanic province, southwestern Idaho. Geol Soc Am Spec Pap 212:119-145

Botz R, Stuben D, Winckler G, Bayer R, Schmitt M, Faber E (1996) Hydrothermal gases offshore Milos Island, Greece. Chem Geol 130:161-173

Brown SJA, Barley ME, Krapež B, Cas RAF (2002) The Late Archean Melita Complex, Eastern Goldfields, Western Australia: shallow submarine bimodal volcanism in a rifted arc environment. J Volcanol Geotherm Res 115:303327

Campos Venuti M, Rossi RL (1996) Depositional facies in the Firiplaka rhyolitic Tuff Ring, Milos Island (Cyclades, Greece). Acta Vulcanol 8(2):47-63

Cas RAF, Landis CA, Fordyce RE (1989) A monogenetic, Surtlatype, Surtseyan volcano from the Eocene-Oligocene WaiarekaDeborah volcanics, Otago, New Zealand: a model. Bull Volcanol 51:281-298

Cas RAF, Allen RL, Bull SW, Clifford BA, Wright JV (1990) Subaqueous, rhyolitic dome-top tuff cones: a model based on the Devonian Bunga Beds, southeastern Australia and a modern analogue. Bull Volcanol 52:159-174

de Rosen-Spence AF, Provost G, Dimroth E, Gochnauer K, Owen V (1980) Archean subaqueous felsic flows, Rouyn-Noranda, Quebec, Canada, and their Quaternary equivalents. Precambr Res 12:43-77

Dewey JF, Sengör AMC (1979) Aegean and surrounding regions: complex multiplate and continuum tectonics in a convergent zone. Geol Soc Am Bull 90:84-92

Dolozi MB, Ayres LD (1991) Early Proterozoic, basaltic andesite tuff-breccia: downslope, subaqueous mass transport of phreatomagmatically generated tephra. Bull Volcanol 53:477495

Fink JH (1980) Gravity instability in the Holocene Big and Little Glass Mountain rhyolitic obsidian flows, northern California. Tectonophysics 66:147-166

Fiske RS, Matsuda T (1964) Submarine equivalents of ash flows in the Tokiwa Formation, Japan. Am J Sci 262:76-161

Fiske RS, Cashman KV, Shibata A, Watanabe K (1998) Tephra dispersal from Myojinsho, Japan, during its shallow submarine eruption of 1952-1953. Bull Volcanol 59:262-275

Fiske RS, Naka J, Iizasa K, Yuasa M, Klaus A (2001) Submarine silicic caldera at the front of the Izu-Bonin arc, Japan: voluminous seafloor eruptions of rhyolite pumice. Geol Soc Am Bull 113:813-824

Fytikas M (1977) 1:25 000 Geological Map of Milos. Institute of Geology and Mineral Exploration, Greece

Fytikas M, Marinelli G (1976) Geology and geothermics of the island of Milos (Greece). Institute of Geology and Mineral Exploration, Greece

Fytikas M, Innocenti P, Manetti R, Mazzuoli R, Peccerillo A, Villari L (1984) Tertiary to Quaternary volcanism in the Aegean region. In: Dixon JE, Robertson AHF (eds) The geological evolution of the Eastern Mediterranean. Geol Soc Lond Spec Publ 17:687699

Fytikas M, Innocenti F, Kolios N, Manetti P, Mazzuoli R, Poli G, Rita F, Villari L (1986) Volcanology and petrology of volcanic products from the island of Milos and neighboring islets. J Volcanol Geotherm Res 28:297-317
Goto Y, McPhie J (1998) Endogenous growth of a Miocene submarine dacite cryptodome, Rebun Island, Hokkaido, Japan. J Volcanol Geotherm Res 84:273-286

Hanson RE, Wilson TJ (1993) Large-scale rhyolite peperites (Jurassic southern Chile). J Volcanol Geotherm Res 54:247264

Hedenquist JW, Henley RW (1985) Hydrothermal eruptions in the Waiotapu Geothermal System, New Zealand: their origin, associated breccias, and relation to precious metal mineralisation. Econ Geol 80:1640-1668

Hoffmann C, Keller J (1979) Xenoliths of lawsonite ferroglaucophane rocks from a Quaternary volcano of Milos (Aegean Sea, Greece). Lithos 12:209-219

Horikoshi E (1969) Volcanic activity related to the formation of the Kuroko-type deposits in the Kosaka district, Japan. Miner Deposita 4:321-345

Houghton BF, Landis CA (1989) Sedimentation and volcanism in a Permian arc-related basin, southern New Zealand. Bull Volcanol $51: 433-450$

Huppert HE, Shepard JB, Sigurdson H, Sparks RSJ (1982) On lava dome growth, with application to the 1979 lava extrusion of the Soufriere of St. Vincent. J Volcanol Geotherm Res 14:199-222

Innocenti F, Manetti P, Peccerilo A, Poli G (1979) Inner arc volcanism in NW Aegean arc: geochemical and geochronological data. Neu Jahr Miner Mona H4:145-158

Jackson JA (1994) Active tectonics of the Aegean region. Ann Rev Earth Plan Sci 22:239-271

Kano K (1998) A shallow-marine alkali-basalt tuff cone in the Middle Miocene Jinzai Formation, Izumo, SW Japan. J Volcanol Geotherm Res 87:173-191

Kato Y (1987) Woody pumice generated with submarine eruption. J Geol Soc Jpn 93:11-20

Keller J (1982) Mediterranean island arcs. In: Thorpe RS (ed) Andesites. Wiley, New York, pp 307-325

Keller J, Rehren TH, Stadlbauer E (1990) Explosive volcanism in the Hellenic Arc: a summary and review. In: Hardy DA, Keller J, Galanopoulos VP, Flemming NC, Druitt TH (eds.) Thera and the Aegean World III. Proceedings of the Third International Congress on the Volcano of Thera, Santorini, vol 1, pp 13-26

Kerr DJ, Gibson HL (1993) A comparison of the Horne volcanogenic massive sulfide deposit and intracauldron deposits of the mine sequence, Noranda, Quebec. Econ Geol 88:1419-1442

Kornprobst J, Kienast J-R, Vilminot J-C (1979) The high-pressure assemblages at Milos, Greece: a contribution to the petrological study of the basement of the Cyclades Archipelago. Contrib Miner Petrol 69:49-63

Ludwig KR (2000) SQUID 1.00, A user's manual Berkeley Geochronology Center Spec Publ 2, 2455 Ridge Road, Berkley CA 94709, USA

Mastin LG (1991) The roles of magma and groundwater in the phreatic eruptions at Inyo Craters, Long Valley Caldera, California. Bull Volcanol 53:579-596

McKenzie DP (1978) Active tectonics of the Alpine-Himalayan belt the Aegean Sea and surrounding regions. Geophys J R Astron Soc 55:217-254

McPhie J, Allen RL (1992) Facies architecture of mineralised submarine volcanic sequences: Cambrian Mount Read Volcanics, western Tasmania. Econ Geol 87:587-596

Mercier JL, Sorel D, Vergely P, Simeakis K (1989) Extensional tectonic regimes in the Aegean basins during the Cenozoic. Basin Res 2:49-71

Minakami T, Ishikawa T, Yagi K (1951) The 1944 eruption of Volcano Usu in Hokkaido, Japan. Bull Volcanol 11:45-160

Muffler LJP, White DE, Truesdell AH (1971) Hydrothermal explosion craters in Yellowstone National Park. Geol Soc Am Bull $82: 723-740$

Nairn IA, Wiradiradja S (1980) Late Quaternary hydrothermal explosion breccias at Kawerau geothermal field, New Zealand. Bull Volcanol 43:1-13

Norman MD (2002) SHRIMP U-Pb zircon age determination of Upper Pliocene mineralising domes, west Milos, Greece. (unpubl. report A02-010), pp 1-20 
Paces JB, Miller JD (1993) Precise U-Pb ages of Duluth Complex and related mafic intrusions, northeastern Minnesota: geochronological insights to physical, petrogenetic. Paleomagnetic and tectonomagmatic process associated with the 1.1 Ga Midcontinent rift system. J Geophys Res 98:1399714013

Papanikolaou D, Lekkas E, Syskakis D, Adamopoulou E (1993) Correlation on the neotectonic structures with the geodynamic activity in Milos during the earthquakes of March 1992. Bull Geol Soc Greece 27(3):413-428

Papazachos BC (1990) Seismicity of the Aegean and the surrounding area. Tectonophysics 178:287-308

Papazachos BC, Pangiotopoulos DG (1993) Normal faults associated with volcanic activity and deep rupture zones in the southern Aegean volcanic arc. Tectonophysics 220:301-308

Pe Piper G, Piper DJW, Reynolds PH (1983) Paleomagnetic stratigraphy and radiometric dating of the Pliocene volcanic rocks of Aegina, Greece. Bull Volcanol 46:1-7

Pichler H (1965) Acid hyaloclastite. Bull Volcanol 28:293-310

Principe C, Arias A, Zoppi U (2002) Origin, transport and deposition of a debris avalanche deposit of phreatic origin on Milos Island (Greece). Montagne Pelee 1902-2002, Explosive Volcanism in Subduction Zones, Martinique 12-16 May, 2002, Abstracts p 71

Principe C, Arias A, Zoppi U (2003) Hydrothermal explosions on Milos: from debris avalanches to debris flows deposits. Southern Aegean Active Volcanic Arc: Present knowledge and future perspectives, Milos Island 17-20 September, 2003, Abstracts p 95

Renfrew C, Wagstaff M (1982) An island polity: the archaeology of exploitation in Melos. Cambridge University Press, Cambridge, UK, $330 \mathrm{pp}$

Reynolds MA, Best JG, Johnson RW (1980) 1953-57 eruption of Tuluman volcano: rhyolitic volcanic activity in the northern Bismarck Sea. Geol Surv Papua New Guinea Mem 7:144

Rinaldi M, Campos Venuti M (2003) The submarine eruption of the Bombarda volcano, Milos Island, Cyclades, Greece. Bull Volcanol 65:282-293

Roth T, Thompson JFH, Barrett TJ (1999) The precious metal-rich Eskay Creek deposit, northwestern British Columbia. Rev Econ Geol 8:357-373

Sewell DM, Wheatley CJV (1994) The Lerokis and Kali Kunning submarine exhalative gold-silver-barite deposits, Wetar Island, Mauku, Indonesia. J Geochem Explor 50:351-370

Smith TL, Batiza R (1989) New field and laboratory evidence for the origin of hyaloclastite flows on seamount summits. Bull Volcanol 51:96-114

Snyder GL, Fraser GD (1963) Pillowed lavas: I. Intrusive layered lava pods and pillowed lavas, Unalaska Island, Alaska U.S. Geol Surv Prof Pap 454 B: B1-B23

Sohn YK (1995) Geology of Tok Island, Korea: eruptive and depositional processes of a shoaling to emergent island volcano. Bull Volcanol 56:660-674

Sonder RA (1924) Zur geologie und petrography der inselgruppe von Milos. Zeitschr Vulc 8:181-231

Staudigel H, Schmincke H-U (1984) The Pliocene seamount series of La Palma/Canary Islands. J Geophys Res 89:11195111215
Stewart AL, McPhie J (2003) Internal structure and emplacement of an Upper Pliocene dacite cryptodome, Milos Island, Greece. J Volcanol Geotherm Res 124:129-148

Stewart AL, McPhie J (2004) An Upper Pliocene coarse pumice breccia generated by a shallow submarine explosive eruption at Milos, Greece. Bull Volcanol 66:15-28

Stüben D, Glasby GP (1999) Geochemistry of shallow submarine hydrothermal fluids from Paleohori Bay, Milos, Aegean Sea. Explor Min Geol 8:273-287

Swanson DA, Holcomb RT (1990) Regularities in growth of the Mount St. Helens dacite dome, 1980-1986. In: Fink JH (ed) Lava flows and domes. IAVCEI Proc Volcanol 2. Springer-Verlag, Berlin Heidelberg, pp 3-24

Traineau H, Dalabakis P (1989) Mise en evidence d'une eruption phreatique historique sur l'ile de Milos (Grece). C-R Acad Sci Paris, pp 1-38

Watanabe KK, Katsui Y (1976) Pseudo-pillow lavas in the Aso Caldera, Kyushu, Japan. J Jpn Assoc Min Pet Econ Geol 71:44 49

Williams IS (1998) U-Th-Pb geochronology by ion microprobe. In McKibben M A, Shanks W C III, Ridley W I (eds) Applications of microanalytical techniques to understanding mineralizing processes, Rev Econ Geol 7:1-35

Winchester JA, Floyd PA (1977) Geochemical discrimination of different magma series and their differentiated products using immobile elements. Chem Geol 20:325-343

Wright IC, Gamble JA (1999) Southern Kermadec submarine caldera arc volcanoes (SW Pacific): caldera formation by effusive and pyroclastic eruption. Mar Geol 161:207227

Wright IC, Gamble JA, Shane PAR (2003) Submarine silicic volcanism of the Healy caldera, southern Kermadec arc (SW Pacific): I-volcanology and eruption mechanisms. Bull Volcanol 65:1529

Yamagishi H (1991) Morphological features of Miocene submarine coherent lavas from the "Green Tuff" basins: examples from basaltic and andesitic rocks from the Shimokita Peninsula, northern Japan. Bull Volcanol 53:173-181

Yamagishi H, Dimroth E (1985) A comparison of Miocene and Archean rhyolite hyaloclastites: evidence for a hot and fluid rhyolite lava. J Volcanol Geotherm Res 23:337355

Yamagishi H, Dimroth E (1987) Studies on the Neogene subaqueous lavas and hyaloclastites in southwest Hokkaido. Rep Geol Surv Hokkaido 59:55-117

Yamagishi H, Goto Y (1992) Cooling joints of subaqueous rhyolite lavas at Kuroiwa, Yaumo, southern Hokkaido, Japan. Bull Volcanol Soc Jpn 37:205-207

Yamamoto T, Tatsunori S, Shigeru S, Kozo U, Akira T, Keiichi S, Koji O (1991) The 1989 submarine eruption of eastern Izu Peninsula, Japan: ejecta and eruption mechanisms. Bull Volcanol 53:301308

Yuasa M (1995) Myojin Knoll, Izu-Ogasawara arc: submersible study of submarine pumice volcano. Bull Volcanol Soc Jpn 40:277-284 [in Japanese with English abstract]

Yuasa M, Murakami F, Saito E, Watanabe K (1991) Submarine topography of seamounts on volcanic front of the Izu-Ogasawara (Bonin) arc. Geol Surv Jpn Bull 42:703-743 